\title{
Explaining path-dependent rigidity traps: increasing returns, power, discourses, and entrepreneurship intertwined in social-ecological systems
}

\author{
$\underline{\text { Pablo F. Méndez }}^{1,2}$, Jaime M. Amezaga ${ }^{3}$ and Luis Santamaría ${ }^{1,2}$
}

\begin{abstract}
The current, unprecedented rate of human development is causing major damages to Earth's life-support systems. Therefore, the need for transitions toward sustainability in the use of natural resources and ecosystems has been extensively advocated. To be successful, such transitions must be guided by a sound understanding of the architecture of the policy and institutional designs of both the process of change and the target outcome. Here, we contribute to current research on the institutional conditions necessary for successful transitions toward sustainability in social-ecological systems, addressing two interrelated theoretic-analytical questions through an in-depth case study focused in the Doñana region (Guadalquivir estuary, southwest Spain). First, we focus on the need for enhanced historical causal explanations of social-ecological systems stuck in maladaptive rigidity traps at present. Second, we focus on the explanatory potential of several factors for shaping maladaptive outcomes, at two different levels of analysis: political-economic interests, prevailing discourses and power, at a contextual level, and institutional entrepreneurship, at an endogenous level. In particular, we address that explanatory potential when the core logic of path dependence fails to predict maladaptive outcomes in a historical, evolutionary perspective. When this occurs, such outcomes are often qualified as unexpected, hence subject to contingency, because of their divergence from purported superior, optimal alternatives. We argue that contingency can be modulated away from randomness and better characterized as unpredictability, through the systematic inclusion of the mentioned factors into analysis. This would, in turn, increase our capacity to inform future policy and institutional transitional designs toward sustainability.
\end{abstract}

Key Words: adaptive inference; discourse analysis; institutional path dependence; maladaptive traps; modulating contingency; politicized IAD framework; power; sustainability transitions

\section{INTRODUCTION}

The increasing extent and impact of human activities is causing habitat and biodiversity loss, land degradation, environmental pollution, and the depletion of many natural resources (Dirzo and Raven 2003, Steffen et al. 2004, MEA 2005, Butchart et al. 2010). As a consequence, ecological and resource systems are increasingly shifting toward undesirable alternative states less suited to maintain human welfare (Rockström et al. 2009, Biermann et al. 2012). Therefore, the need to facilitate the transition toward sustainability has been extensively advocated by the policy making and scientific communities (see, e.g., Brundtland Report 1987, Raskin et al. 2002, Loorbach and Rotmans 2006, Levin and Clark 2010, Haberl et al. 2011, Markard et al. 2012, Moore and Tjornbo 2012). In general, successful sustainability transitions require a sound understanding of the governance, the policy, and the institutional architecture needed for both the process of change and the target outcome (Loorbach and Rotmans 2006, Olsson et al. 2008, Young 2010, Markard et al. 2012).

We explore a set of interrelated theoretic-analytical questions about the institutional conditions necessary for successful sustainability transitions in social-ecological systems (SES). At a general level, we are interested in the need for enhanced historical, causal explanations for the genesis and evolution of SES stuck in maladaptive traps (Holling et al. 2002), in particular rigidity traps (see, e.g., Beier 2011, Herrfahrdt-Pähle and Pahl-Wostl 2012, Méndez et al. 2012). Maladaptive traps are departures from the adaptive cycle heuristic posed by resilience theory to characterize, in conceptual terms, event dynamics, structural change, and causality in SES as they evolve through time (Holling et al. 2002). In SES stuck in rigidity traps, there is a historical tendency to a mutual reinforcement of power, politics, and profit, and to the recurrent use of command-and-control approaches for governance and management. In the long run, those approaches have been found to (1) hinder change, smother innovation, and squeeze out diversity, (2) diminish ecosystems' resilience, thus increasing their vulnerability, and (3) promote socioeconomic dependence on limited sets of resources (Gunderson et al. 1995, Holling and Meffe 1996, Holling et al. 2002).

More specifically, we are interested in the explanatory potential of the following factors for the historical formation of rigidity traps in SES, at two different levels of analysis: political-economic interests, prevailing discourses, and power at a contextual level (see, e.g., Pritchard and Sanderson 2002, Armitage 2007, Smith and Stirling 2010, Voß and Bornemann 2011, Moore and Tjornbo 2012, Clement and Amezaga 2013) and institutional entrepreneurship at an endogenous level (see, e.g., Westley et al. 2013, McCarthy et al. 2014). We will discuss the explanatory potential of those factors when the core logic of path dependence, composed by the mainstream principles of neoclassical economics, fails to predict observed outcomes in a historical, evolutionary perspective. When this occurs, such outcomes are often qualified as unexpected because of their divergence from purported superior, optimal alternatives, hence subject to contingency. Here, based on an epistemological paradox created by the notion of contingency, we make the case for the orderly

\footnotetext{
${ }^{1}$ Spatial Ecology Group, Doñana Biological Station (EBD-CSIC), Seville, Spain, ${ }^{2}$ Laboratory of Spatial Ecology, Mediterranean Institute for Advanced Studies (IMEDEA, CSIC-UIB), Esporles, Mallorca, Spain, ${ }^{3}$ School of Engineering, Newcastle University, Newcastle upon Tyne, United Kingdom
} 
inclusion of the mentioned factors into the analysis, so as to increase our capacity to predict the likelihood of certain types of maladaptive outcomes in SES.

We address these theoretic-analytical questions through an indepth case study design focused on the Donana region (Guadalquivir Estuary, southwest Spain; Fig. 1), an estuarine SES affected by intricate socioeconomic, water resources, and wetland conservation problems. To guide the analysis, we use a recent extension made to the Institutional Analysis and Development framework (Kiser and Ostrom 1982, Ostrom 2005), which has produced a politicized version (Clement 2010, Clement and Amezaga 2013).

\section{METHODOLOGICAL APPROACH}

The research presented here followed from previous work published in Méndez et al. (2012), and it is part of a long-term program of social-ecological research focused in the Doñana region. The program follows an iterative process (Fig. 2) of theoretical evaluation against empirical information with both scientific and normative goals. The process is guided by an adaptive inference procedure (Holling and Allen 2002) and operationalized through a methodological approach consisting of three main components: (1) an in-depth single-case study design (Yin 2009); (2) the politicized version of the Institutional Analysis and Development framework; (3) a reasoned elaboration of theory subject to thorough assessment.

\section{Case study design}

The research iteration presented in this paper (2nd research iteration in Fig. 2) builds on a previous iteration focused on the historical explanatory pattern underlying Doñana's (Fig. 1) current institutional regime (1st research iteration in Fig. 2; Méndez et al. 2012). Méndez et al. (2012) concluded that the Doñana region is currently governed by a rigid institutional regime and stuck in a systemic maladaptive "rigidity trap" (Holling et al. 2002), highly dysfunctional for coping with socialecological crises and unable to harmonize wetland conservation, water management, and economic development (see also GómezBaggethun and Kelemen 2008, Martín-López et al. 2011, Palomo et al. 2011 for similar interpretations). The historical analysis of Méndez et al. (2012) suggested that the institutional regime followed a path-dependent dynamic characterized by the historical persistence of command-and-control policy panaceas. In a seeming paradox, command-and-control approaches failed to drive the region toward an (optimal) efficient outcome, leading it instead to system-wide inefficiencies and a rigidified outcome (Doñana outcome hereafter). Méndez et al. (2012) assessed the Doñana outcome as unexpected or, more generally, as contingent against the efficiency and productivity baseline of neoclassical economics that lies at the core of the theory of path dependence.

In the second iteration, we re-examine, challenge, and refine the historical explanatory pattern described above. We aim at exploring how to increase predictability or, as we call it, how to modulate contingency in the maladaptive Doñana outcome, by taking a richer array of causal factors into the analysis. To make our case, we have further developed two key conceptualizations from Méndez et al. (2012): (1) path dependence, by revisiting an extensive literature review drawing from economic history, historical sociology, historical institutionalism, and political science in a somewhat disciplinary phylogenic fashion; (2) the notion of contingency, by emphasizing the epistemological paradox that it creates at the core of path dependence theory. To attain a proper balance in our case study between its capacity to provide novel empirical insights and its power to assess effectively our theoretic-analytical questions, we focused on a well-bounded unit of analysis: the institutional events and actors of the transformational process of Doñana's floodplain marshlands into irrigated and rice agriculture, all mainly fed by surface water, as part of the right bank of the Guadalquivir estuary (Fig. 1). We thus simplified the case by excluding historical and institutional events and actors from other processes and geographical scales that, as we already knew from Méndez et al. (2012), do not influence nor confound significantly the factors and phenomena studied in the selected unit of analysis.

\section{The politicized Institutional Analysis and Development framework}

The Institutional Analysis and Development (IAD) framework is a systematic method for understanding how institutions operate and change over time (Kiser and Ostrom 1982, Ostrom 2005). It categorizes relevant explanatory factors and locates them within a foundational structure of logical relationships that allows for their analysis, as a prelude to understand how they are interrelated and shape outcomes (McGinnis 2011). For greater detail on the original IAD and how it applies to our overall research program, see Appendix 1. Here we focus on how the politicized version of the IAD (pIAD; Clement 2010, Clement and Amezaga 2013) contributed to make us aware about the explanatory potential of (1) discourses and their relationship with institutions and power at a contextual level of analysis, and (2) institutional entrepreneurship at an endogenous level of analysis. Whereas the former were introduced into the analysis a priori, the latter was introduced in hindsight.

\section{Contextual factors: discourses and their relationship with institutions and power}

The pIAD enhances the capabilities for institutional analysis of the IAD by integrating the political-economic context, discourses, and power into the analysis, and placing them in a historical perspective (Fig. 3). As originally devised, the pIAD envisages discourses as constitutive elements of institutions, owing to their capacity to reinforce or undermine their credibility, i.e., to confer power to institutions (Clement 2010). Because discourses have actors' values and beliefs built-in, they hold a capacity to mobilize power, thus acting as drivers of policy and institutional dynamics (Clement 2010, Clement and Amezaga 2013). In turn, such dynamics are shaped by the political-economic context and the pre-existing institutional practices in which they are embedded, in a dynamic two-way interaction (Clement 2010, Clement and Amezaga 2013). In fact, discourses are posed as holding a capacity for illuminating explanations about institutional dynamics, e.g., mechanisms at work, answering of "how" questions (Hajer and Versteeg 2005). In sum, discourses are linked to institutions not only by affecting their formation, but because "the emergence and persistence of discourses depend on the institutional and political-economic context" (Clement 2010:140, based on Hajer 1995). Philosophically, the pIAD adopts a post-structuralist approach to power, by combining Lukes' (2005) third-view and Foucault's (1979) conceptions of power (Clement 2010, see also Clement and Amezaga 2013). 
Fig. 1. Geographical location of the Doñana region. Source: our own development from POTAD (2003), Castells et al. (1992; Almonte-Marismas Plan boundaries), and Gómez-Baggethun et al. (2012; broader Doñana social-ecological system boundaries).

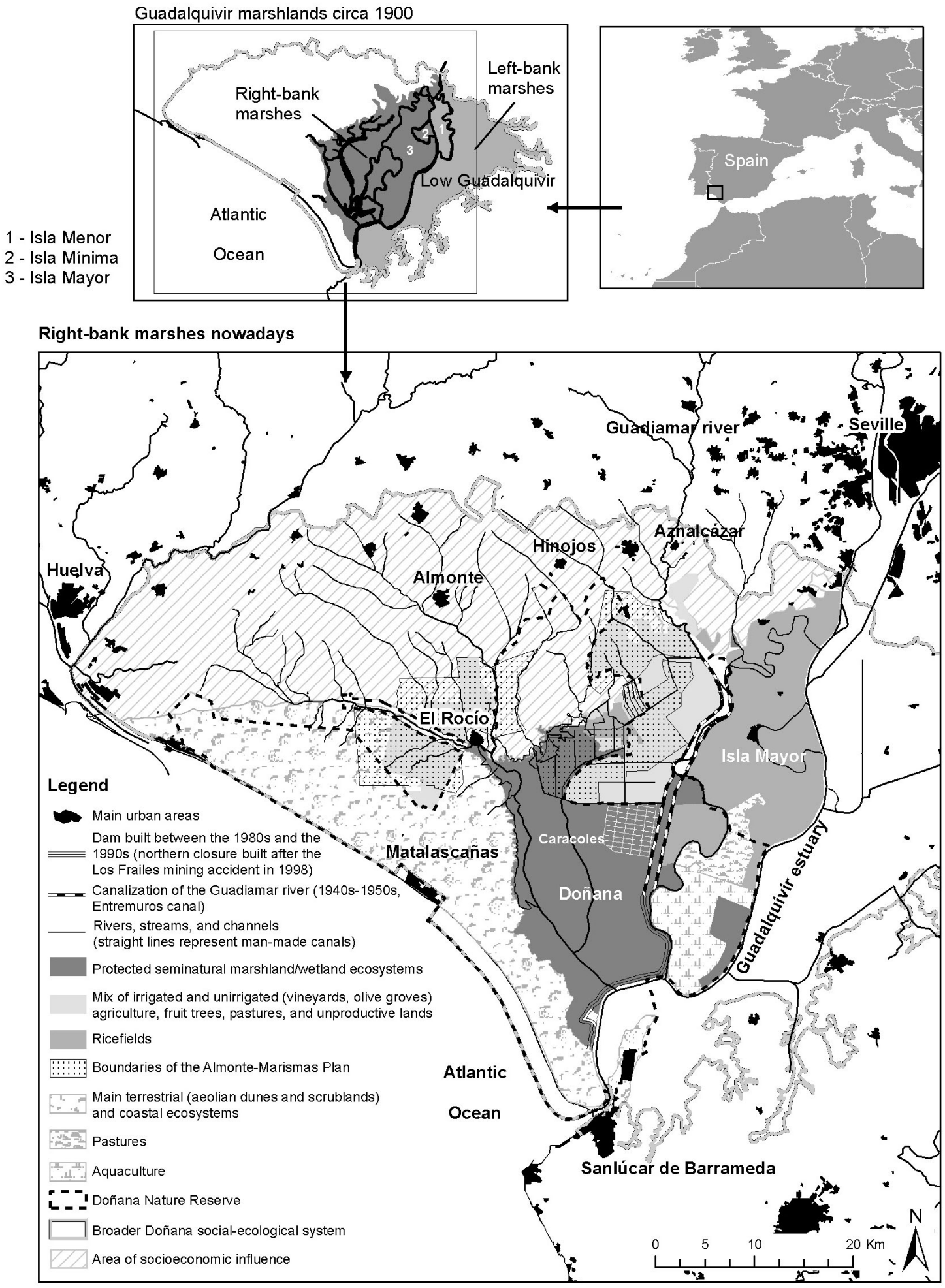


Fig. 2. Iterative process, methodological approach, and adaptive inference procedure of our social-ecological research program in Doñana, Spain. IAD framework = Institutional Analysis and Development framework; pIAD $=$ politicized version of the IAD. Source: modified from Holling and Allen (2002).

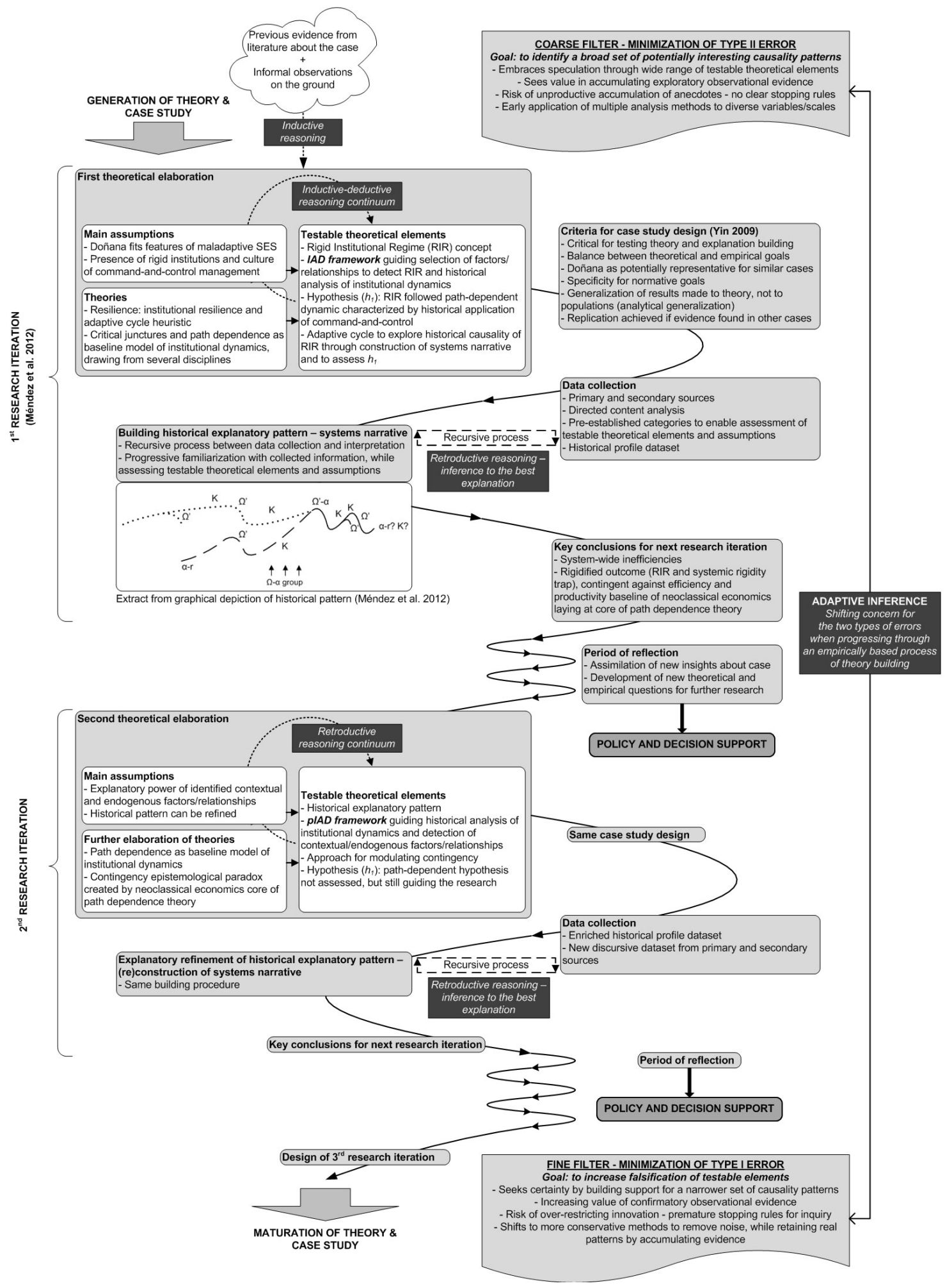


Fig. 3. The politicized version of the Institutional Analysis and Development framework. Source: modified from Clement (2010) and Clement and Amezaga (2013).

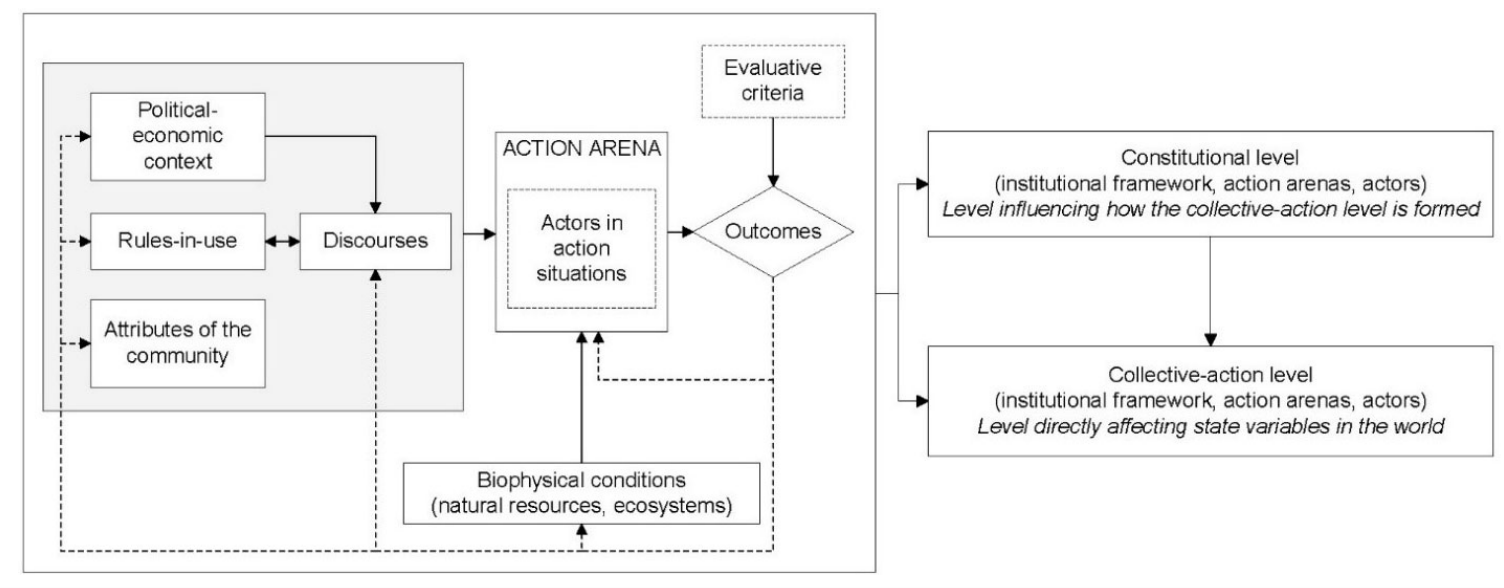

Taking those conceptions into account, we ground our analysis on a wide structuralist and post-structuralist linguistic philosophy to discourse and power analysis. Our chosen epistemological orientation conceives human's access to reality as largely mediated by discourse (as language) to create representations that are both reflections of such reality and contributions to its creation (Jørgensen and Phillips 2002). From that point of departure, we define discourses as homogeneous and organized regularities of categorizations and concepts conveying ideas, knowledge, or meaning about objects from the world, which actors exchange through oral or written interactive means (based on Adger et al. 2001, Hajer and Versteeg 2005, Clement 2010). Our definition emphasizes a twofold property of discourses: (1) they are homogeneous and overarching patterns of thought and languagein-use that contain the ideas, knowledge, or meaning of actors about certain world phenomena, as well as about the causality of problems and adequate responses to them, e.g., through certain courses of action and practices; (2) they are dynamically conveyed by actors, thus contributing to the production and reproduction of objects and subjects in the world. Discourses exert power because they transport the base knowledge that founds the individual and collective action that shapes reality (Jäger and Maier 2009).

We focus on the influence, over our unit of analysis, of a hegemonic, top-down discourse conveying ideas about political and socioeconomic regeneration of the fatherland (the so-called "regenerationism" movement), which emerged in Spain by the end of the 19th century. We narrowed down the focus to that discourse for several reasons: (1) we had gathered substantial evidence about its potential contribution to Doñana's maladaptive state (Méndez et al. 2012), but our ideas about how it contributed to such state remained untested; (2) its study constituted a self-contained research iteration worth developing to extract relevant research and normative lessons and insights; (3) our research design did not exclude future research analyzing, through the pIAD, the explanatory contribution of other discourses, sources of power, and actors' interests, at the same or at a reduced level of analysis.
Endogenous factor: institutional entrepreneurship

Whereas contextual factors were introduced a priori in the research, institutional entrepreneurship was introduced in hindsight, upon realizing that our analysis was still insufficient to provide a satisfactory refinement to the explanation about the Doñana outcome. The historical operation of several seemingly illogical infrastructure and biophysical processes, raised critical concerns about how and why certain actors proceeded to action at operational levels, in spite of large failures and huge uncertainties in either expected outputs or the benefits to be obtained from those processes. The IAD and, by extension, the pIAD, provide the foundations for an analysis of how actors consider and integrate mistakes of the past, for example, by setting norms and rules, or by effective learning driven by negative feedback, i.e., actors as fallible and adaptive learners vs fully informed and rational maximizers (Ostrom 2005). However, those frameworks lack a component allowing the analysis of how adaptive learning is actually operationalized in situations characterized by high uncertainty on the effect of human action upon real-world SES, i.e., the effect of collective action at the IAD-defined operational level upon the biophysical system (see Appendix 1). To enable that analysis in a complementary way to the pIAD, we drew from advancements in the literature showing how institutional entrepreneurs have a great competency to transform SES in situations of high uncertainty, through social and environmental innovation processes by, for example, working to (1) change beliefs "by convening all stakeholders around a common vision"; (2) diversifying "the flow of political authority and resources ... by playing key roles in networks and mobilizing social capital"; or (3) challenging "technical and legal frameworks ... by encouraging integration of local knowledge, experimentation, and new scientific frameworks" (Westley et al. 2013).

\section{Theoretical elaboration}

We base this research on our particular synthesis of path dependence and the notion of contingency that lies at its core, creating an epistemological paradox. Our elaboration is based on an extensive literature review, from which we provide working definitions (see below), a graphical depiction (Fig. 4) and a fully referenced report (Appendix 1). In this section, we present 
Fig. 4. Graphical idealization of the concept of path dependence and the epistemological paradox created by the notion of contingency at its core (based on Mahoney 2000), departing from the concept of path independence. For simplification purposes, process/outcome dynamics have been depicted using sinusoids.

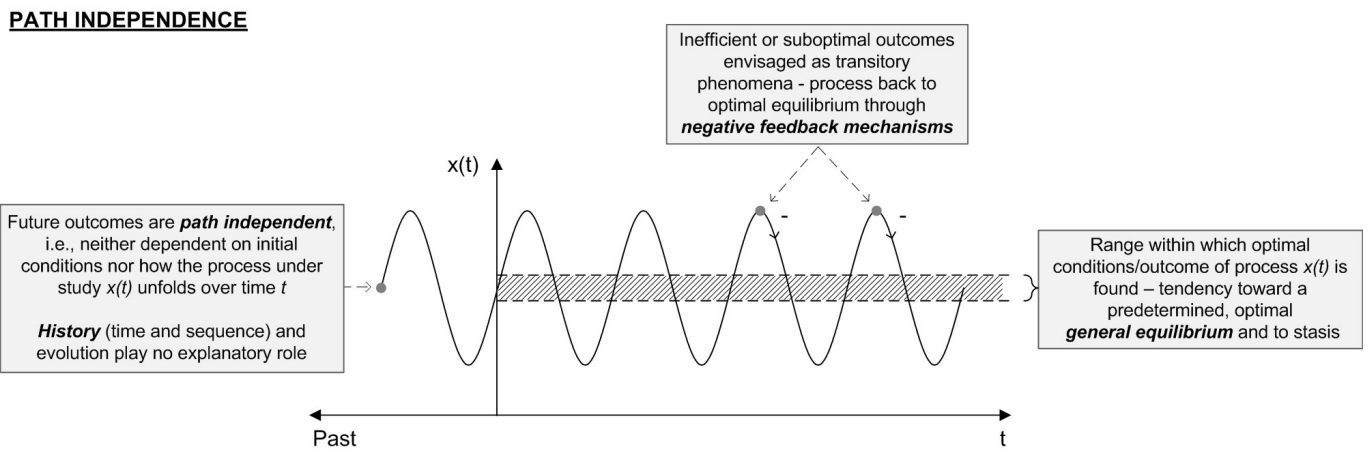

\section{PATH DEPENDENCE}

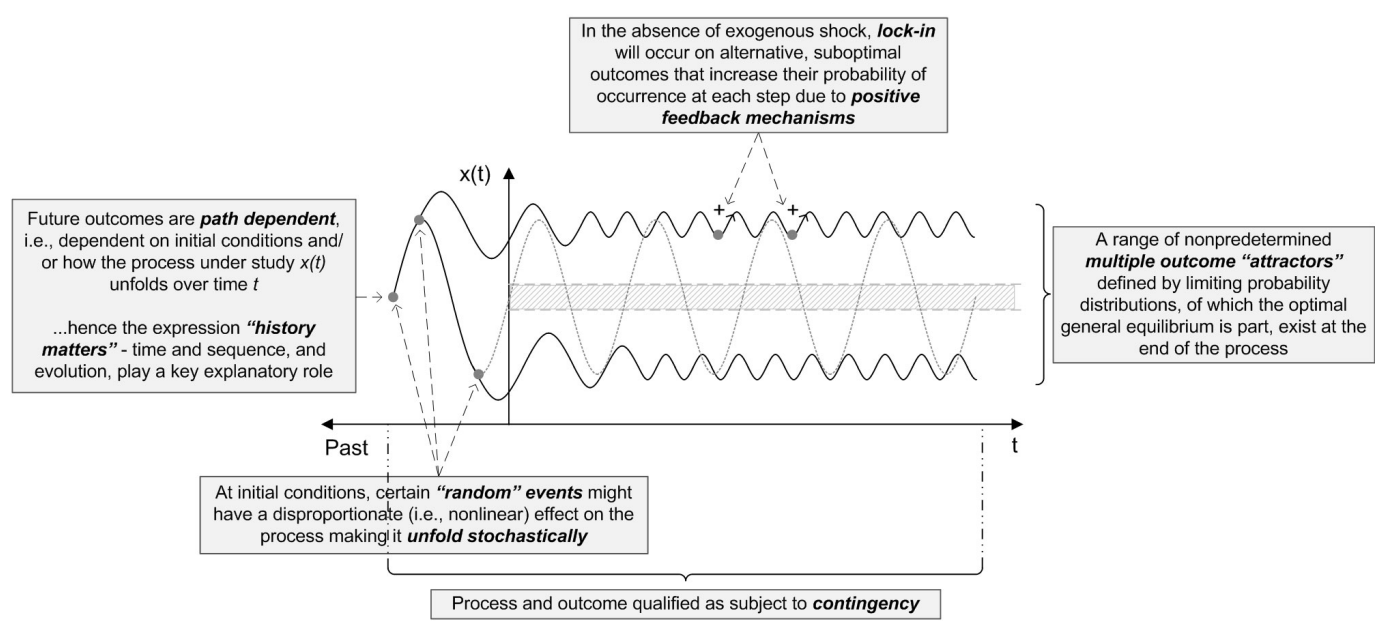

CONTINGENCY: AN EPISTEMOLOGICAL PARADOX

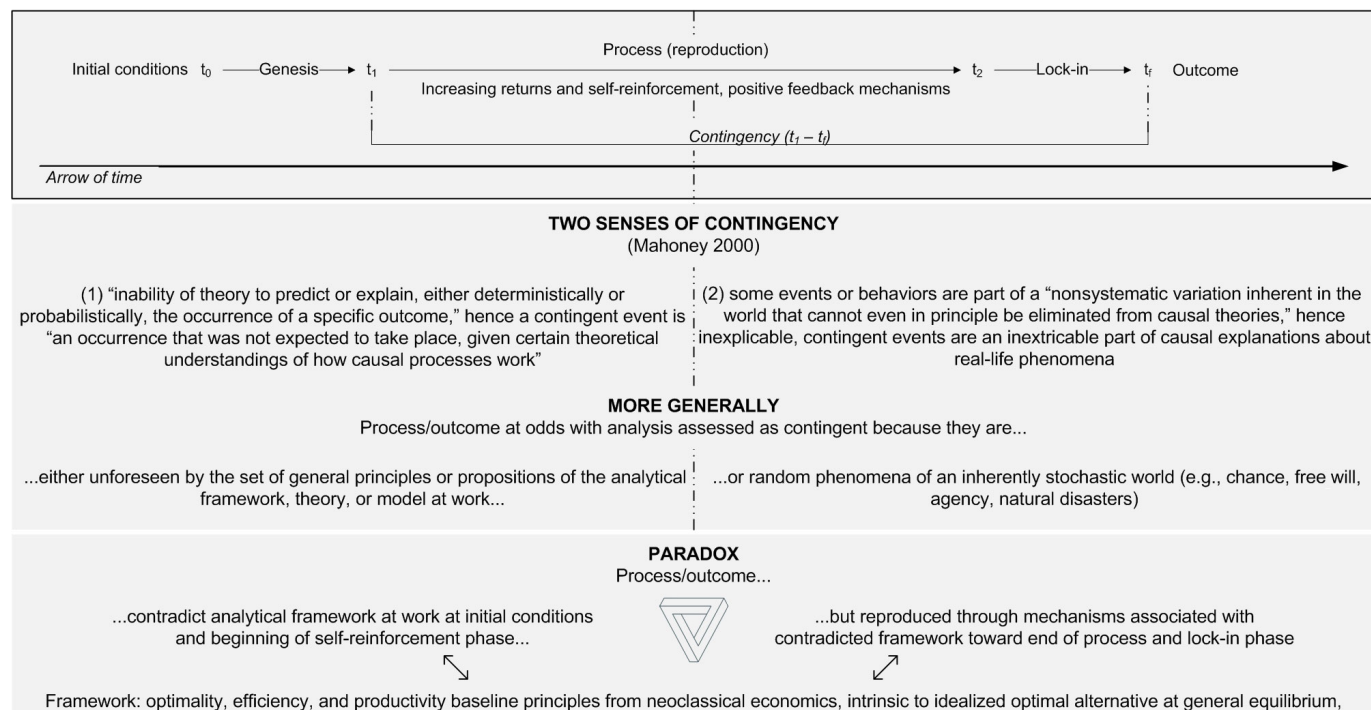


theoretical content about the use of path dependence in the study of institutional dynamics, as well as about the role of politics, ideas, and power.

\section{Path dependence}

Path dependence (Fig. 4) challenges the assumption made by neoclassical theory that technological and economic action always move toward increasingly efficient outcomes, i.e., solutions or designs. Inefficient outputs are envisaged as transitory phenomena and notions of dynamics are restricted to movements toward a highly abstract, invariant general equilibrium. Negativefeedback mechanisms, e.g., decreasing returns, competitive pressures, or price signals, offset major changes and lead the setting, in a linear fashion, toward the predicted optimal equilibrium. Outcomes are path independent, i.e., they are predetermined and independent of how the initial conditions and the history of technological or economic development unfolded over past time. Hence, the role of history and evolution can be disregarded. Institutions are envisaged as arrangements exogenous to the technological or economic process; their development is driven by a constant, rational search for efficiency by actors seeking to improve their individual welfare, thereby arriving at mutually beneficial, collective outcomes.

Path dependence theory poses, in contrast, that institutions may become locked in alternative, suboptimal outcomes that diverge from optimal and more efficient, "superior" alternatives. These outcomes depend on the initial conditions and how the history of technological or economic development unfolds over time. Seemingly small, random events can have unexpected, disproportionate effects on the process, i.e., nonlinearity, making it unfold in a stochastic fashion. The probability of occurrence of the suboptimal outcome increases at each step of the process owing to increasing returns, whereby decisions by actors favoring certain choices, e.g., technology, increase the attractiveness of these choices for other actors, in terms of pay-off or utility. Underlying increasing returns, there are self-reinforcing mechanisms: positive feedback mechanisms that result in selfreinforcing patterns, e.g., learning and coordination effects. In path dependence studies, these outcomes and processes are assessed as random, unexpected, or, more generally, as subject to contingency, assessed against neoclassical economics principles. This qualification creates an epistemological paradox.

\section{Contingency: an epistemological paradox}

We are concerned with a specific epistemological tension between two senses of contingency in path dependence as established by Mahoney (2000), which we have depicted in Figure 4. The key of the paradox lies in that explanations about the end of the process and lock-in phase rely on the same, negative feedback mechanisms associated with neoclassical theory (e.g., constant or decreasing returns), which are contradicted by what is occurring at initial conditions (e.g., randomness, unpredicted or illogical behavior) and beginning of self-reinforcement phase (e.g., increasing returns), i.e., by actual events or behaviors. In the institutional realm, this focus on neoclassical economics (in particular, on its utilitarian core) results in a failure to theorize different mechanisms to explain institutional dynamics (Mahoney 2000). The two significations identified by Mahoney are two attributes representing two extremes of contingency, respectively referring to pure randomness or chance, and pure predictability (after Eagle
2005; Fig. 4). Between both, a continuum of predictability unfolds, with randomness equating a high level of unpredictability. Events or behaviors that are considered random or unexpected under certain epistemological devices might be explicable or predictable by alternative devices; hence, randomness might be more properly assessed as unpredictability, at least to some degree. In other words, the outcome under analysis can be assessed as contingent by certain theoretical notions, yet be consistent with the expectations of alternative theories positing causal links accounting for such outcome. Hence the following questions: Can we modulate contingency away from randomness and assess it as unpredictability in path dependence studies? Can we thus turn certain outcomes into more predictable objects by using more comprehensive epistemological devices such as, in our case, the politicized IAD framework?

\section{Path dependence in studies of institutions}

North $(1990,1991)$ generalized path dependence as a core concept in explanations of institutional differences between diverse social and economic systems showing an unexpected stability in spite of a history of poor economic performance. He argued that institutions are subject to the same self-reinforcing mechanisms as technological and economic processes, in particular, to what he terms as "massive increasing returns" (North 1990:94-95). However, contrary to Arthur's (1988) views, North considers the latter as a necessary but not sufficient condition for path dependence. For him, the lock-in of suboptimal outcomes prevails regardless of the efficiency of alternative institutional configurations because of other conditions such as the prohibitive transaction costs of switching or reversal, the imperfection of the market, and the limited rationality of the actors (North 1990).

Here, we understand self-reinforcing mechanisms underlying increasing returns as the "set of mechanisms endogenous to a given path that makes it more and more dominant over time relative to alternative paths"(Vergne and Durand 2010:755). They include: (1) large setup or fixed costs, which create a high pay-off for further investment in an already established single option; (2) learning effects, if knowledge gained in the recursive operation over the resource system or ecosystem lead actors to be more efficient and get higher returns from continuing use; (3) coordination effects, if the individual benefit increases as others adopt the same option; (4) adaptive expectations, whereby increased prevalence of selected options enhances beliefs of further prevalence (adapted from Arthur 1988, North 1990). Nevertheless, certain incomplete analogies must be made explicit when path dependence concepts are transported across disciplinary levels (Woerdman 2004). In this research, we apply the analogy to increasing returns made by Woerdman (2004), based on North's insight. That analogy, which Woerdman (2004) argues as incomplete, is made from technology and economics to institutions, as follows. Economic increasing returns imply that the production costs of a technology declines as fixed costs are spread over an increasing production volume. For institutions the analogy is not an increased production of institutions, e.g., rules or legislation, but the decreasing costs of adding them as "the institutional scale increases" (Woerdman 2004:61), as well as the increasing potential benefits that this phenomenon signals to lower level actors. 
The role of politics, power, and ideas

The above advancements were then applied in political science (e.g., Pierson 2000a) and historical sociology (e.g., Mahoney 2000). In those fields, because of the existence of actor constellations, the core logic of path dependence in technology and economy constitutes only the utilitarian argument of the discussion, there being other mechanisms bearing explanatory power, namely, asymmetric power relations, functional logics, legitimacy claims, the accumulation of mutual commitments, the complex compound of inherited institutions, and the significance of collective action (Mahoney 2000, Pierson 2000a, $b)$. From the standpoint of political science, institutional dynamics are not just determined by mere rational responses to a series of inefficiencies that are seen as transitory, but also by political struggles over different interests and distributions of power. For Pierson (2000b), political actors, seeking to reinforce their authority and power, might favor and induce further movement along a particular path by influencing public policies and institutions. In contrast to the view of institutional conditions in an inertial state of irreversibility, the political view of path dependence emphasizes more how present and future possibilities of change are the residue of a richer set of past alternatives at the initial conditions stage, most of which are no longer available (Pierson 2000b). Institutional dynamics are envisaged as restricted and change as bounded by mechanisms, e.g., counter-reactions, grinding down other mechanisms that would otherwise lead to reproduction and continuity (Pierson $2000 \mathrm{~b}$ ). Power asymmetries inherited from past institutions result, in practice, in an array of opportunities and constraints influencing the nature of governance and the calculation of rulers (Lewis 2007).

For some, increasing returns "do not happen automatically," but most often must "be cultivated by actors" (Deeg 2001:12). That happens through the mobilization of power and ideas that promote their interests and mediate institutional change or stabilization, e.g., mobilization in the political arena on behalf of policy or regulatory change, organization of collective action, coalition building (Deeg 2001). Utilitarian mechanisms such as increasing returns may get exhausted and be replaced by power mechanisms (e.g., coercive measures, state-enforced monopolies, delegated enforcement powers), activated by dominant actors to reproduce institutions so as to retain their positions, i.e., to maintain the status quo. Eventually, the advent of decreasing returns may force dominant actors to arrange new institutional configurations (Schwartz 2004, unpublished manuscript, http:// www.people.virginia.edu/ hms2f/Path.pdf), triggering, if not, path changes without any obvious exogenous cause (Deeg 2001). In fact, some have argued that political conflict, especially those over ideas and underlying political/institutional assumptions, do have a primary role in explanations of institutional dynamics (Peters et al. 2005). More generally, it is argued that institutional dynamics require a theory of ideology accounting for deviations from the predictions of neoclassical economics, e.g., altruistic behavior, obedience, and inefficiencies, in which context, culture, and ideas are not uncritically reduced to simply how information is distributed and used (Fine 2000). North (1991:98) stresses the existence of choice points along the path, at which actors have the opportunity to mobilize in support of a preferred choice, therefore loosening the automaticity of path dependence development. Indeed, more than three decades ago, North argued that assumptions of economic rationality in neoclassical economics cannot account for certain phenomena (North 1981) and turned to the development of a theory integrative of the role of ideology in institutional dynamics and economic change (North 2005).

We seek to contribute to the development of such an integrative theory within the SES and resilience thinking fields. This research iteration tackles that contribution through the qualitative analysis of discourses understood as conveyers of ideas, knowledge, and meaning, and being both a constitutive power of institutional dynamics and amenable for empirical analysis to illuminate explanations about such dynamics. We also seek to contribute to the mentioned fields with regard to path dependence more generally, by means of our above conceptualizations, which are both core to its pivotal usage (see Boonstra and de Boer 2014 for a similar approach) and complementary to other approaches, e.g., path dependence resulting from output institutional inertia (Österblom et al. 2011) or as a result of social-ecological memory (Nykvist and von Heland 2014).

\section{Operationalizing the analysis}

The historical pattern developed by Méndez et al. (2012) was built into a systems narrative. Here, data analysis, inference, and theorizing are approached through a careful narrative (re) construction. We progressed in several stages of data collection and data analysis, interpretation, back and forth in a recursive process (Fig. 2). This allowed us to gain a progressive familiarization with the collected information, while looking for evidence and patterns that matched or mismatched the theoretical propositions and assumptions under evaluation (Yin 2009). Our information sources consisted of an enriched (though admittedly partial) version of the historical profile of Méndez et al. (2012) and, for discourse analysis, of primary and secondary document sources including research articles and books, technical reports, and policy and legislative documents. The enriched historical profile can be found in Appendix 2 (Table A2.1), and the discursive data in Table 1.

\section{RESULTS AND DISCUSSION}

To guide the reader through our explanations in the present theoretical iteration, which refines the Méndez et al. (2012) historical pattern, we provide a synthesis of key institutional events and actors from the mentioned pattern (see Fig. 5 and the short narratives provided in Appendix 3). To concretize our theoretical elaboration, we relied on the comprehensive definition of path dependence as "a property of a stochastic process which obtains under two conditions (contingency and self-reinforcement) and causes lock-in in the absence of exogenous shock" (Vergne and Durand 2010:741). Applying it to the historical pattern's component parts, we specified the phases analyzed in the present research, which take root in a "critical juncture" explained by Méndez et al. (2012; Fig. 5, $\mathrm{t}_{1}$; not analyzed here). In particular, we specified two phases posterior to that critical juncture, and for reasons that will become evident below, were characterized as increasing-returns phase (up to 1937, Fig. 5, $\mathrm{t}_{1 \mathrm{~A}}-\mathrm{t}_{2 \mathrm{~A}}$ ) and selfreinforcement phase (1937-1980s; Fig. 5, $\left.t_{2 A}-t_{3 A}\right)$.

\section{Setting the scene for the outcome}

In general, the transformational process between the initial conditions and 1980 (Fig. 5, point 1; Appendix 3, link 1) yielded a large-scale implementation of technologies and engineering 
Table 1. Main attributes of the hydraulic-irrigation regenerationist discourse.

\begin{tabular}{ll}
\hline \hline Attribute & Description $^{\dagger}$ \\
\hline Roots & Enlightened reformism and liberalism of the previous two centuries. Examples: program for agrarian development proposed by J. \\
& Costa to the High Chamber of the Upper Aragón (1892-1893); Enlightened Plan of Promotion of the Province of Sanlúcar de
\end{tabular}

Political- $\quad$ Fin-de-siècle Agrarian Crisis: readjustment of global agricultural trade, loss of overseas colonies triggering increases in tariff economic context barriers for traditional unirrigated crops (cereals, vineyards, and olive groves).

Disenchantment with the poor results obtained by past liberalist, laissez-faire hydraulic policies using various incentives (subsidies, economic aids, and fiscal exemptions) to foster the private sector as the main driver in the building of primary hydraulic infrastructure.

Huge public drive toward infrastructure development (roads, railways, and hydraulic infrastructure) through new types of subsidies, economic aids, and fiscal exemptions, aimed at incentivizing the coparticipation of the private sector, for example, in the irrigation business, i.e., toward the material reconstruction of the country.

Chronic budgetary crisis and contemporary deficit of government finances following the Cuban War.

Main expressive Media (newspapers, e.g., El Imparcial), official documents (planning documents, e.g., National Plans of Hydraulic Works(,

means legislation, e.g., Gasset Act, Cambó Act); institutional (speeches, e.g., before the Parliament, in agricultural organisations).

Features Irrigation agriculture (intensive and industrial) as a privileged means for economic modernization throughout the country, focusing on modernization and increased production, thus avoiding the alternative option of land reform and redistribution to reduce the rampant inequality between laborers and land owners.

Ideas about the need to maximize water use efficiency, inherited by the anterior period of Liberal Reform and forwarded as the key for the consolidation of the liberal state.

Hydraulic policy as a reconstructive economic policy. North-south hydrological differences conceived as a geographical imbalance (topographic and climatic), whose resolution would, in turn, resolve the ancient Spanish agrarian problem and the "ills afflicting the fatherland" (from the Spanish los males de la patria).

The need for the state to build and exploit primary hydraulic infrastructure was "common sense doctrine," based on the argument that costly public investments constituted reproductive spending.

Representative characters: Rafael Torres Campos, Ricardo Macías Picavea, Fermín Caballero, Lucas Mallada, Andrés Llauradó, Horacio Bentabol, Pedro M. González Quijano, Celedonio Rodrigañez, Joaquín Costa, Rafael Gasset, Lorenzo Pardo.

Illustrative

discursive

fragments

"It is urgent to rebuild the geography of the country, in order to resolve the political and social matters" (Costa 1911).

"Current social and agricultural progress in Spain depends on rainwater, and water springs and reservoirs. Such water must be the task of the nation, and the agricultural Congress must address both the Parliament and the Government for their urgent claim, as the supreme desideratum of Spanish agriculture" (Costa 1911).

"... [T] he day that all the water of the Pyrenees remains in the plain, our province alone will produce as much as ten provinces together, and there will be for all, income and luxury for the rich, independence and well-provided table for the poor, high and uninterrupted wages for workers, substantial alms to the destitute, large payments to the treasury, rest and comfort for all..." (Costa 1911).

"Canals and reservoirs must be built by the State; if built by the private sector, the remedy would be worse than the disease" (Costa 1911).

"...government must be willing to take charge, as a function of the State, the building of canals and reservoirs, for which it will present, within a year, a bill for a general Plan aiming at such purpose" (Gasset 1899, as cited in Sánchez 1997:324).

Key conceptions Water of rivers is lost to the sea, hydrological differences constitute a geographical imbalance (topographic and climatic), existence and dichotomies of "two Spains" (wet North and dry South), two types of basins (ones negatively balanced and others positively balanced), need for hydro-solidarity among regions.

Sources: own elaboration based on the primary and secondary sources consulted. Main secondary sources include, e.g., Ortí (1984), Moral-Ituarte (1991), Gómez-Mendoza (1992), Sánchez (1997), Fernández (2000).

works on the ground aimed at reducing the natural variation in the Guadalquivir estuary and its floodplain marshlands, including Doñana's hydro-ecological system (see Table A2.1, Appendix 2 for evidence). This sought to decrease natural complexity and uncertainty, in order to maximize agricultural production, inland water shipping, and return on investment over the short term. Although the second half of the 20th century witnessed large agricultural transformations and the emergence of a highly productive, technically efficient rice sector, the whole process signals a high contingency (Fig. 5) against the static principles of neoclassical economics based on two encompassing grounds:

1. Early failures: The majority of the first agricultural attempts along the increasing-returns phase (Fig. 5, $\mathrm{t}_{1 \mathrm{~A}}-\mathrm{t}_{2 \mathrm{~A}}$ ) repetitively ended in productivity, infrastructural or financial failures (Table A2.1). A priori, this might indicate either that informational, negative feedback mechanisms did not operate efficiently at any point to make actors react and readjust their approaches in subsequent enterprises, or that actors were subject to random, irrational behavior.

2. Illogical decisions: The full development of rice and irrigation agriculture in the Guadalquivir marshlands at both banks of the estuary along the self-reinforcement phase (Fig. 5, $\mathrm{t}_{2 \mathrm{~A}}-\mathrm{t}_{3 \mathrm{~A}}$ ), appears as illogical for several reasons that we shall develop below.

Regarding rice agriculture, the unfavorable biophysical features of the estuary and the marshlands create severe salinity and water supply problems, posing economic barriers that proved difficult to overcome (based on Enggass 1968, Grande-Covián 1977, 
Fig. 5. Synthesis of Méndez et al. (2012) historical explanatory pattern, including information about key institutional events, actors, and transformations on the ground. $\mathrm{TM}_{1}$ specifies the periods established in Méndez et al. (2012); $\mathrm{TM}_{2}$ specifies the time markers resulting from the explanatory refinement presented here, based on the definition of path dependence of Vergne and Durand (2010). IR = increasing returns; SR = selfreinforcement.

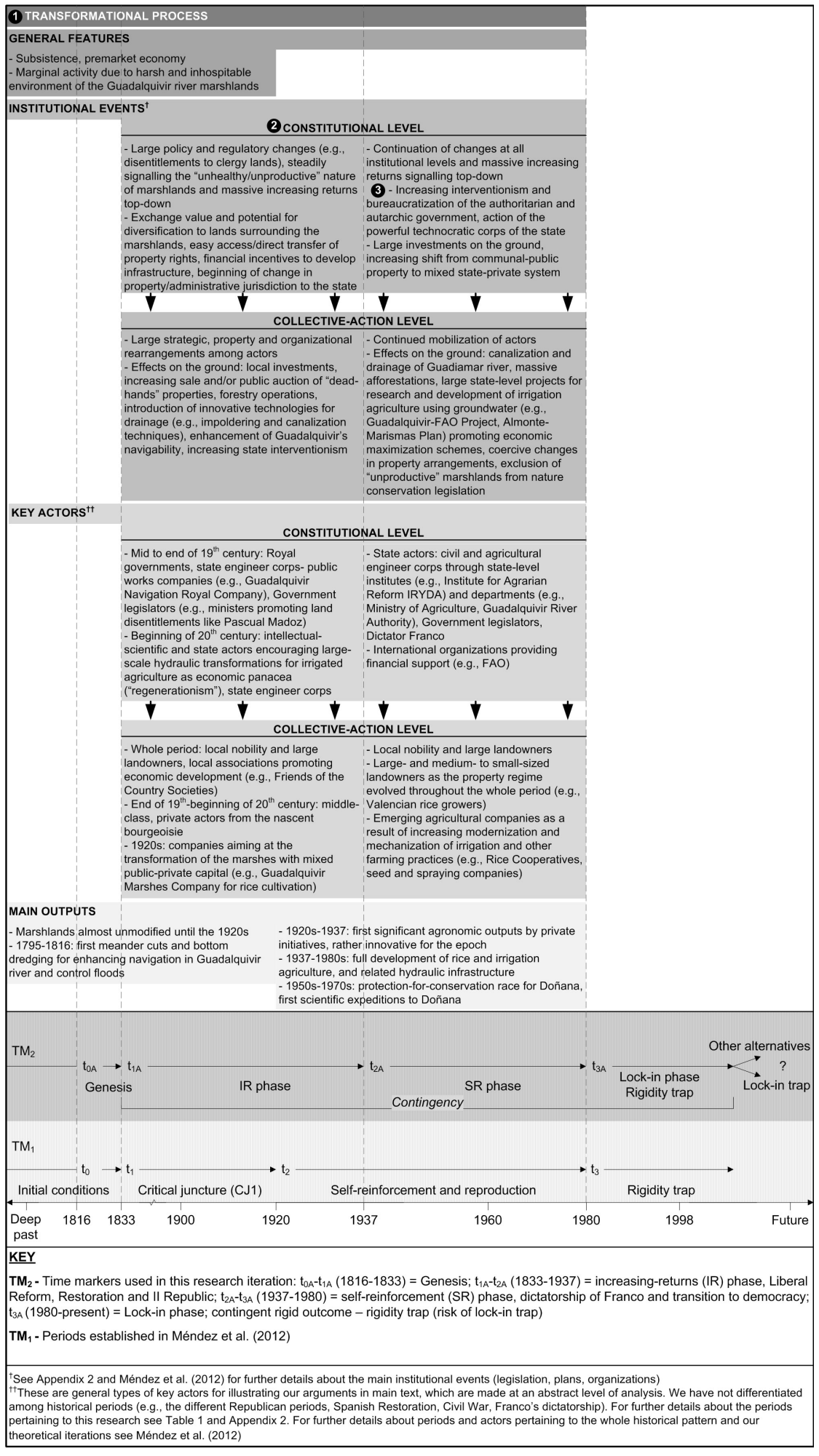


Corominas 1995, Santamaría et al. 1996, Blomquist et al. 2005, González-Arteaga 2005, Parry et al. 2012):

- The strongly seasonal temperature and rainfall regime, characteristic of a subhumid Mediterranean climate, cause within-year flow deficiencies for irrigation, and multiyear droughts that exacerbate such water deficits.

- The moderate-high, NW-SE salinity gradient results in salt deposits and thick saline crusts (in the upland and the lowland soils, respectively) during summer. This occurs in synergy with the high imperviousness of the soils and with the horizontality of the marshlands, which prevent the regular washout of salts and fine elements.

- The low slope of the last stretch of the estuary and the geomorphology of the single-channel mouth of the river, which combine to allow (i) the tidal ebb to penetrate up to 90-100 km inland; (ii) a greater penetration of the salinity wedge, whose length, concentration, and movements depends on the oscillations of both daily tides and seasonal freshwater.

From the short-term-maximization standpoint of neoclassical economics, these biophysical features combined to make the economic development based on agricultural transformation of the self-reinforcement phase a counterintuitive endeavor, for the following reasons. First, although the topographical and climatic conditions of the marshlands potentially matched the needs of several crops, rice was the most adapted alternative to the harsh saline conditions (Sumpsi 1980, Moral-Ituarte 1993, Portero et al. 2007, Muñoz 2009). Choosing the optimal crop was, however, a long-term lesson learned after a prolonged process of speculation and experimentation, whose recurrent, negative outcomes did not fit well with neoclassical logic.

Second, rice agriculture was in full operation by the 1980s-1990s and, being one of the most technically advanced sectors in the world, its cultivation was already well adapted to the territory and generating significant agronomic yield and economic gain in an arguable regime of constant returns to scale. Indeed, Sumpsi (1980) argues that maximum profitability of rice production was reached between 1948 and 1955, and then started to decline until a minimum level was reached by the end of the 1960s. MoralItuarte (1991) documented a structural saturation, from the 1960s onward, in the hydraulic intervention at the level of the Guadalquivir River basin, caused by an increased awareness of an emerging imbalance between water supply and demand. Today, rice cultivation occupies approximately 34,900 ha, equivalent to $35 \%$ of the marshlands (Portero et al. 2007). By the $1990 \mathrm{~s}-2000 \mathrm{~s}$, it constituted the livelihood of more than 6000 families and yielded between 262,000 and 342,000 tonne per year (TPY) in normal rainfall years. This meant, in unit yields, about 7.5-10 $\mathrm{TPY} /$ ha, doubling the average global yield and constituting 10 $15 \%$ of EU's production (based on Castroviejo 1993, MoralItuarte 1993, Corominas 1995, González-Arteaga 2005, Portero et al. 2007). However, the high salinity and the limited water availability have recurrently challenged (and still does today) rice agriculture viability and profitability from the outset. Rice, which must be cultivated during spring-summer because of its mild temperature requirements, needs huge freshwater resources to get the optimum salinity level allowing for normal growth $(<0.8 \mathrm{~g} / \mathrm{L}$, upper tolerance threshold 1.5-2 g/L; Corominas 1995, GonzálezArteaga 2005, Muñoz 2009). Water demand, estimated nowadays at a volume of $10,000-12,000 \mathrm{~m}^{3} / \mathrm{ha}\left(8000-9000 \mathrm{~m}^{3} /\right.$ ha if recycling processes are taken into account), has been traditionally met by resources collected from the Guadalquivir River and the local aquifer through pumping systems, complemented with urban waste effluents, and managed through a complex and costly system of sluice gates and canals (Castells et al. 1992, Moral-Ituarte 1993, Portero 2001, Blomquist et al. 2005, Muñoz 2009). All this requires a costly hydraulic infrastructure that collect and distribute water, and, in the view of the époque engineers, transformed several thousand hectares of "saline desert" into productive irrigated croplands: "Reclaiming the land for cultivation would involve these processes: preventing the inflow of outside waters, draining off the precipitation falling into the impoldered zone, and lowering the ground-water table" (Grande-Covián 1960, as cited in Enggass 1968:128).

Let's therefore make the following counterfactual. What if such infrastructure had not been constructed by the 1950s, when the growth of the rice sector commenced at a relevant rate? What if a large part of such infrastructure had not been publicly backed, e. g., through top-down coercive changes in the property system, public investments, strong legal and tax incentives (Table A2.1)? It is hard to imagine that any idealized neoclassical actor at $t_{2 \mathrm{~A}}$ (Fig. 5) would have made a rational decision toward any type of efficient allocation of resources seeking the transformation of the marshlands into agricultural land, hence a profitable investment: (a) if knowledgeable of the failures of the increasing-returns phase; (b) in the absence of hydraulic infrastructure for irrigation and salinity regulation. In fact, the transformational processes were only possible owing to the intervention of the state in the double role of undertaking key infrastructure development and subsidizing large capitalist companies with high capacity for technological development (Moral-Ituarte 1993, Ojeda-Rivera and Moral-Ituarte 2004). Today, thorough calculations remain undone, but rough estimates indicate that the total investment in irrigation infrastructure undertaken by the Guadalquivir River Authority between 1939 and 1987 came to 197,000 million Pesetas (Moral-Ituarte 1991:512) or $€ 1182$ million (equivalent to more than $€ 43,808.5$ million at present, using the 1961-2018\% change in the general CPI $=3706.3 \%$, Spanish National Institute of Statistics, since there are no CPI data for years prior to 1961). In addition, a neoclassical actor could not have envisioned a rice sector highly competitive in the market, since, ceteris paribus, e.g., energy and water prices, market and surplus regulations, external financial inputs such as subsidies, the Guadalquivir sector would have been outcompeted by other regions not limited by water availability. In fact, in pure market terms, the Guadalquivir rice sector is arguably of limited overall economic efficiency outside the European Union's protectionist scheme (Castells et al. 1992, Moral-Ituarte 1993, González-Arteaga 2005, Portero et al. 2007).

Finally, the ensuing development of irrigation agriculture at the right bank, with the support of FAO (Table A2.1), is also at odds against the neoclassical baseline for two main reasons. First, the experiences of the left-bank transformational process show that the recovery of saline soils required a publicly funded, long-term costly process of hydraulic drainage that considerably reduced the 
prospects for short-term economic profitability. Second, there was a lack of (1) technical training and specialization among the local farmers, hence the skills necessary to undertake a high-risk intensive agriculture very different from rice growing; (2) financial and commercialization structure and capacity to optimize the benefits from the crops and related agricultural products. This eventually contributed to a deep economic crisis in the 1990s that made it necessary for the intervention of the Andalusian regional government (Rubio-Recio 1977, 1993, Castells et al. 1992, Corominas 1995). The total cost of the drainage system through canals, underground pipes, and water pumps to enable irrigation agriculture is still uncertain, but by the 1990s it was argued that any economic assessment would have resulted in a negative balance (Rubio-Recio 1993). In fact, the World Bank provided a negative evaluation of the economic viability of the project as early as 1962 (Rubio-Recio 1993). Calculations made in 1992 estimated the total costs of the transformation $(15,000 \mathrm{ha})$ at 55,000 million Pesetas, the private family debt at more than 2300 million Pesetas, and the economic viability plan to overcome crisis at 1500-1700 million Pesetas (amounting, respectively, to $€ 12,231.8, € 511.5$, and $€ 333.6-€ 378.0$ million at present; Castells et al. 1992, Castroviejo 1993).

In sum, the transformational process and the outcome in Doñana can be assessed as unexpected and, more generally, as contingent, for it defies the universalistic principles of neoclassical economics. The latter cannot account for the transformational process described by the historical pattern, at least not in isolation. We now turn to the task of working out the why and how that transformation happened. Our more specific questions are the following: (1) Was the process that led to the Doñana outcome triggered by irrational, unexpected, or random events and behaviors, or was it unpredictable because of an incomplete analytical framework? In other words, can such outcome be predicted using a more complete framework? (2) What is the explanatory potential of political-economic interests, discourses, and power as factors contributing to shape the Doñana outcome?

\section{Refining Doñana's historical pattern: steps toward modulating contingency}

Here we discuss three sets of mechanisms that reduce the unpredictability associated to the Doñana's rigid outcome. Some elements of the first two sets are described in detail in the historical pattern developed by Méndez et al. (2012). We focus on their explanatory potential by arguing how the three sets have operated over time, and by justifying their necessity and sufficiency as conditions for the emergence of the outcome (see Table A2.1 for the evidence).

\section{Increasing returns}

Massive increasing returns were signaled from the constitutionallevel institutional matrix, throughout Doñana's whole transformational process (Fig. 5, point 2; Appendix 3, link 2). Learning and coordination effects operated along the increasingreturns and the self-reinforcement phases. Additionally, during the self-reinforcement phase, large setup costs (once the first large irrigation infrastructures were in place, in the early 1950s) and adaptive expectations (once the rice sector started its full development and entered the national and global market, in the 1960s-1970s) started to operate. It was then after 1937, when a clear and systemic self-reinforcement pattern started to unfold, that the Doñana region was pushed toward a certain trajectory. And it was the realization of that dynamic that led us to characterize the 1937-1980s period as a "self-reinforcement phase," different from the previous "increasing-returns phase." The latter, although also characterized by some of the selfreinforcing mechanisms that underlie increasing returns, did not show signs of a systemic self-reinforcement dynamic, at least not one as difficult to reverse as the one that took place after 1937 because of massive increasing returns, large setup costs, and the deep adaptive expectations pervading the collective-action level.

Can these phenomena and behavior be qualified as irrational or random? We argue against such characterization. Collectiveaction actors were behaving neither randomly nor illogically, but responded instead through positive feedback to the constitutional institutional matrix, a higher structural entity. Borrowing from David (2007), it is misleading to pose economic irrationality or implementation errors in Doñana, because collective-action actors were subjected to positive network externalities, e.g., coordination effects. They were, if something, picking "the right horse," based on their expectations and projections on how the future was to unfold. Hence, they adapted their actions "in ways that help make those expectations come true," having and following adaptive expectations (Arthur 1994:112). They were responding to the driving force of incentives, which, in the words of North (1990:112), constitutes one of "the most constructive building blocks of neoclassical theory."

However, this set of mechanisms constituted a necessary but not sufficient condition for the emergence of the outcome. Although our results agree with the insight that increasing returns can result in alternative, far-from-equilibrium paths (if an equilibrium does exist at all), its selection may also result from the occurrence of externalities and other mechanisms decreasing the likelihood of such paths or the attractiveness of other alternatives (Arrow 2000, Kay 2005, Vergne and Durand 2010).

Politics, discourses, and power

The historical pattern describes several top-down, political and power mechanisms at the constitutional level that played a key role in decreasing the attractiveness of alternative courses of action during the self-reinforcement phase (Fig. 5, point 3; Appendix 3, link 3). Together with the bottom-up (increasing returns) mechanisms described in the previous section, these topdown mechanisms contributed to reduce the unpredictability associated to the rigid outcome. However, the notion of contingency continues to be very powerful, for it still signals a bizarre historical process, especially along the self-reinforcement phase. The arguments derived from the historical pattern that (1) collective-action actors were inefficiently allocating resources in response to speculative expectations on massive increasing returns produced by the institutional framework, and (2) constitutionallevel actors were reproducing command-and-control for the sake of power and economic maximization logic, are not satisfactory in isolation. It is striking that command-and-control continued to pervade the institutional framework, and that the large-scale transformational process started and progressed on the ground, in spite of negative feedbacks signaling broad operational inefficiencies and of other policy and institutional alternatives with significant socioeconomic potential at the self-reinforcement phase, e.g., the costs and consequences of doing nothing; the 
preservation and empowerment of traditional economic and ecological knowledge; the promotion of nature conservation, scientific research, and nature tourism.

At this point, observing the constitutional-level institutional events and actors' behavior through the lenses of the pIAD, we realized that another crucial factor was playing a major causal role in the determination of the outcome. It prompted, in particular, a strong command-and-control institutional logic in Doñana. We refer to a discursive factor related with "regenerationism," an intellectual movement that emerged in the 19th-20th change of century, aimed at explaining objectively the decline of Spain as a global economic and political power. It operated at different institutional levels in diverse sectors like politics, economic policy, science, and education. We were especially interested in its effect over the Doñana region because it conveyed the idea of irrigation agriculture and hydraulic infrastructure as a panacea for economic prosperity (see also Swyngedouw 1999). We shall refer to that discourse as the "hydraulic-irrigation regenerationist discourse" (HIR discourse hereafter; see its main features in Table 1).

During the Restoration period (1874-1931), the HIR discourse was absorbed at a political level owing to decisive actions taken by the Civil Engineering Corps and by Rafael Gasset, who was several times minister of public works. They intensively promoted the main arguments of Joaquín Costa, the key ideologist of the hydraulic-irrigation paradigm, in both the media and the Parliament (Ortí 1984, Díaz-Marta 1989, Gómez-Mendoza 1992, Sánchez 1997, Mateu 2002). This contributed to a progressive shift of the state from a mere subsidiary of hydraulic infrastructure, to the active promotion and implementation of such a type of infrastructure (Table A2.1). This shift formed part of a more general, long-term plan that consisted of three broad political-economic stages: (1) a period of material reconstruction of the country through the construction of primary infrastructure, e.g., roads, railways, hydraulic infrastructure, led by the state and financed through the emission of public-debt instruments; (2) a period of settlement of the debt that was being generated by the emission of such instruments; (3) progressive inhibition of the state from economic life (Sánchez 1997). However, implementations on the ground were very limited. During the 1920 s, until 1933, just about $12 \%$ of the planned primary infrastructure and irrigated land surface had been carried out, funded through the emission of public debt instruments justified as investments with long-term returns based on taxable income (see Sánchez 1997, Fernández 2000). During this period, the overtly liberal HIR discourse played mainly a rhetorical role and utopian unifying symbol based on powerful logics $(\log o s)$ and capacity to appeal to emotion (pathos; Table 1). During the II Republic (1931-1939), there were reformist attempts at the agrarian level, but the National Plan of Hydraulic Works (NPHW) of 1933 inherited the hydraulic character and regenerationist mark of the Water Act of 1879 (repealed more than one century afterward, in 1985), the Restoration's NPHW of 1902, and the subsequent revisions of the latter (Ortega 1984, Moral-Ituarte 1991, Gil 2001). During Franco's dictatorship (1939-1975), the largely technical NPHW of 1933 was fully implemented through the (almost identical) NPHW of 1940 (Table A2.1). Franco's government abandoned the agrarian reformist aspects of the 1933 plan, but undertook the major hydraulic transformations of the 20th century (Table A2.1).
Three radical institutional changes took place at this point in time. First, at the constitutional, strategic level, was the interventionist character of both the Irrigation Act of 1932 and the NPHW of 1933, inherited by the NPHW of 1940. The state financially assumed, in full, the construction of primary and secondary irrigation hydraulic infrastructure, and took a main role in the colonization-and-development strategies (Sánchez 1997, Gil 2001, Moral-Ituarte 1991, Barciela and López 2003). Second, at an administrative level, there was the creation of the Water Union Confederations (precursor of the modern Water Authorities), semiautonomous organizations guaranteed financially by the Ministry of Public Works, in 1926 (Table A2.1). They were entrusted with the management and maximization of the agricultural, forestry, and hydropower yield of water resources at the basin level, bringing together the widest range of regional stakeholders, but promoting the national interest to the detriment of local ones (Sánchez 1997, Gil 2001). Third, at the ideological level, there was an emphasis on the need to establish a hydrological balance between the Atlantic and the Mediterranean basins, based on the argument of the higher agricultural productivity and economic potential of the former, and the lack of planned works implemented in the latter (Ortega 1984, Gil 2001).

In the Guadalquivir estuary, the HIR discourse started to exert an effect in the 1920s, providing impetus to the first private companies for transforming the Guadalquivir marshes into a "new Nile delta" (Sabuco 1997:56; Table A2.1). The public and private transformational attempts that took place during that decade occurred under the protection of legislative (e.g., Cambó Act) and incentivizing (e.g., financial and tax-reduction instruments, direct transfer of property rights, no need to justify investments) instruments charged with regenerationist ideas (Table A2.1). In particular, they promoted the transformation of an extensive typology of lands traditionally considered as unhealthy and unproductive, such as lagoons, marshlands, and wetlands. The largest regional transformations started during the 1940s, and reached their maximum impact during the 1960s and the 1970s, under the protection of a battery of regulations deeply rooted in history (Table A2.1). During these two decades, a number of primary hydraulic infrastructures started or planned in previous periods by the state, private companies, or the Guadalquivir River Authority, were completed (Table A2.1). The action of the latter, created in 1927, was crucial in two main senses: ideologically, because of its mandate to maximize resource yield (Moral-Ituarte 1991); operationally, because of its role in regulating and streamlining irrigation activities all over the basin, through reservoir control (Moral-Ituarte 1991), which has been fundamental in the development of technically efficient rice agriculture in Doñana. All these changes were protected legislatively (e.g., Colonization of Large Areas Act of 1939) and rooted in the acknowledgement, by the NPHW of 1933, that regulation was crucial for the irrigation in the marshlands already transformed for "sanitation and colonization" purposes (Pardo 1933:209).

At this point of the analysis, however, these two broad bottomup (increasing-returns) and top-down (politics, power, and HIR discourse) mechanisms appeared as still insufficient to provide a satisfactory explanation about the Doñana outcome. The high uncertainties posed by the water supply and salinity problems elaborated above raised the following question: How and why did collective-action actors proceed to transformation in spite of the 
huge uncertainty on either the output of the transformational process or the benefits to be obtained from rice agriculture? We argue that the dual entrepreneurial component analyzed in the following section must be added up as a necessary endogenous condition.

\section{Dual entrepreneurship component}

This component consists of two endogenous processes of innovation. In the economic development realm, there is the action of Rafael Beca and the Valencian rice growers. The first was an experienced entrepreneur that managed to initiate the full development of the rice sector in Doñana, which would eventually end in a market-based economy. The Valencian rice growers constituted a pioneering workforce attracted by Beca that introduced crucial innovations and productive factors for rice cultivation. In the nature conservation realm, there is the action of a group of private actors led by J. A. Valverde, which was successful in championing a potent nature conservation counterdiscourse locally reactive to the contemporary, intensive socioeconomic development and agricultural transformations. And this is how history went.

Uninterrupted rice cultivation in the Guadalquivir marshlands started in the midst of the Spanish Civil War. In 1937, Rafael Beca was entrusted with the development of rice agriculture in Isla Mayor by the Francoist faction, in order to ensure rice supplies, because the main rice production centers were in hands of the Republican faction (Sabuco 1997, González-Arteaga 2005). Beca received political, financial, and technical support and carte blanche from the recently established dictatorial regime, through the Guadalquivir River Authority, and the National Institutes of Colonization and Housing. From 1939 onward, a long-term transformation process ensued characterized by (1) the state traditional interventionist colonization-and-development strategy; (2) a constant increase in both the number of rice growers and cultivated surface that curbed in the 1960s-1970s (concentration of land ownership); (3) a shift from an experimental period (1940s) characterized by minimal use of technology, to a largescale process of increasing modernization, e.g., full mechanization of direct sowing, use of enhanced seed varieties, herbicides, combine harvesters, and rice drying techniques; (3) sustained growth (1980s-1990s; Sumpsi 1980, Moral-Ituarte 1993, González-Arteaga 1993, 2005).

First Valencian rice growers arrived in the 1940s. This workforce was first attracted by an advantageous tenancy regime and the promise of future ownership offered by Beca because he was aware of the novel productive factors that they brought along with them, amongst the most important being (1) a differential, intrinsic belief in the feasibility and economic profitability of rice agriculture in the marshlands based on previous experiences, which contrasted with the local history of extractive, subsistence economy, and the associated skepticism toward any transformational attempt (this belief soon diffused among part of the already established, mostly Andalusian, workforce); (2) the importation of innovations and know-how from developments in similar areas from their homeland, e.g., Valencia Coastal Lagoon, which outcompeted other techniques imported in the past from the Nile or the Ebro deltas to Doñana; (3) a rather novel, familybased work culture oriented around rice growing, in which women played a major role reconciling housework and farming tasks
(González-Arteaga 1993, 2005, Corominas 1995, Sabuco 1997, Muñoz 2007).

Finally, we have the innovative action of the group led by Valverde, which eventually led to (1) a protection-for-conservation race for the salvation of Doñana's remnant marshland and wetland ecosystems in the 1950s-60s; (2) the purchase, by the newly created WWF, of crucial marshland areas, which entrenched the "battle" against agriculture throughout the 1960s; (3) the creation of the Doñana National Park in 1969 (currently embedded in the wider Doñana Nature Reserve; see Fig. 2). For a more detailed description of the process see Valverde (2004) or Méndez et al. (2012).

\section{Synthesizing the discussion}

At the national level, the HIR discourse had an enormous ideological power that originated during the 19th century and was institutionalized along the Restoration period, independently of the governing party, liberal or conservative (Fig. 6, point 1). Afterward, the HIR discourse paved its way toward the ensuing periods embedded in the institutional matrix at the legislative, strategic, and operational levels (Fig. 6, point 2).

In turn, the institutional matrix produced regularized expectations and patterns of interaction among collective-action actors, due to the increasing returns that it signaled downstream of the constitutional level (Fig. 6, point 3). Such actors were responding to opportunities and constraints that were socially shaped, embedded in the institutional framework, and cognitively powerful; i.e., they were not just merely responding to external incentives of unknown origin. It can therefore be argued that hydraulic development and the irrigationist culture would have been improbable without the presence of a discourse deeply structuring the consciousness and view of reality of all-level actors (see also the views expressed by López-Gunn 2009, MoralItuarte 2009, Paneque and Vargas 2015). This, in turn, constrained their choices, practices, courses of action, and ways of solving problems, and, to a great extent, legitimated the institutions under development, thus limiting their possibilities for transformative agency. Locally, borrowing from Schwartz (2004, unpublished manuscript), the events and behaviors occurring in Doñana during both the increasing-returns and selfreinforcement phases, which neoclassical economics would assess as random, irrational, or illogical, were in fact specific manifestations of larger structural forces. The HIR discourse favored the unfolding of the entrepreneurial component (Fig. 6, point 4), allowing two contrasting processes: first, the innovative action of Beca and the Valencian rice growers to take place, which, in turn, facilitated the development of irrigation agriculture; second, the (re)action of the group led by Valverde, aimed at salvaging (the remains of) Doñana's ecosystem from the ongoing process of agricultural transformation.

Given our arguments, can randomness be exhausted and the contingency signal abated in Doñana? Do our results therefore invalidate the path dependence hypothesis established by the historical pattern (Méndez et al. 2012)? We argue not, for two main reasons. First, within a complex SES, socioeconomic processes lead to deep biophysical and ecological transformations that are largely irreversible, giving rise to early lock-in situations that are very persistent because of the high sunk costs generated, thus eliminating feasible alternative paths at their roots, not to 
Fig. 6. Graphical depiction of the mechanisms that contributed to the emergence of the Donana's systemic rigid outcome. HIR = hydraulic-irrigation regenerationist.

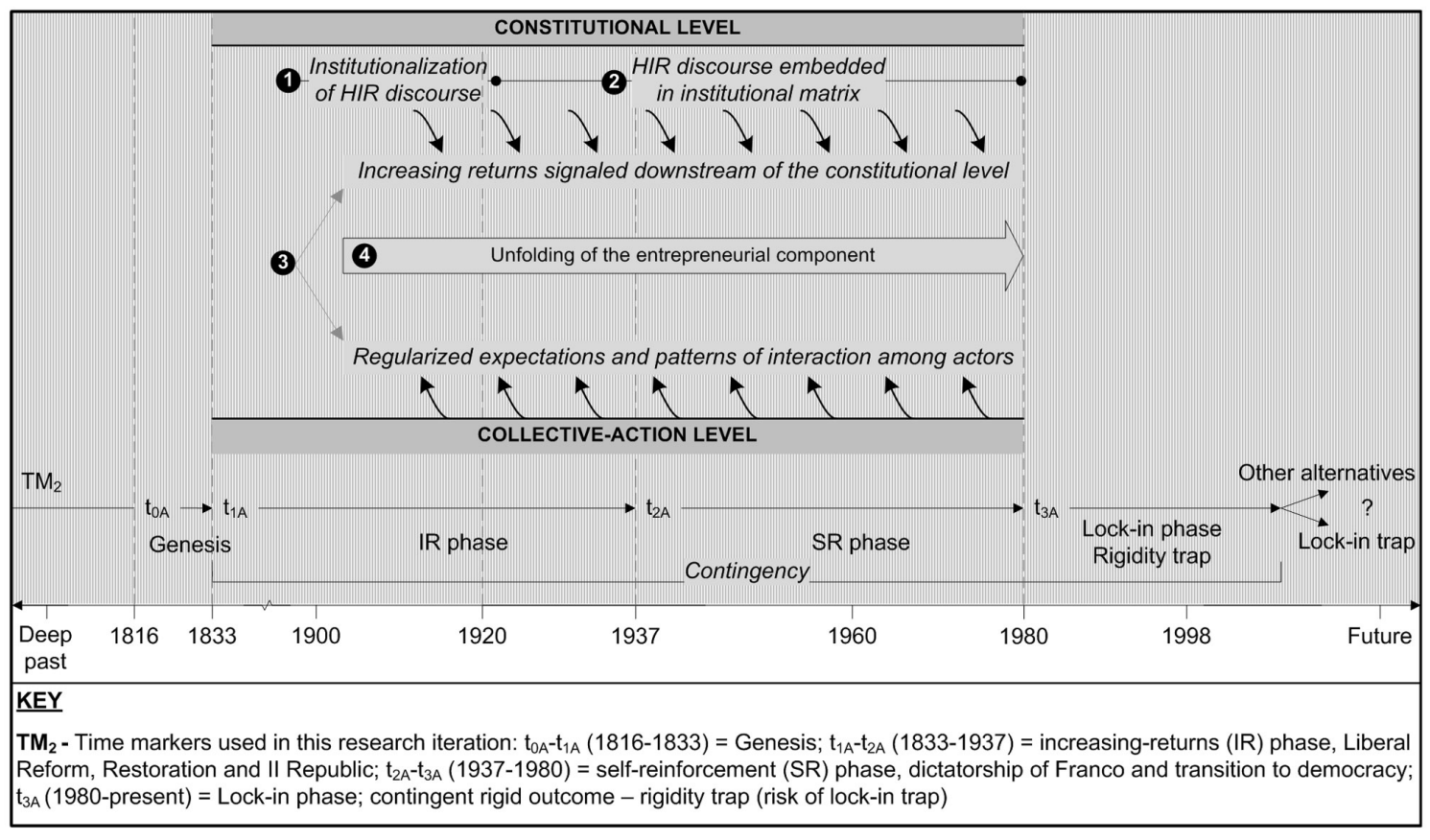

mention the high transaction costs involved in a potential process of institutional and hydro-ecological change. Second, there is the unpredictability associated with human agency, personified by illustrative actors such as Beca, the Valencian rice growers, and the group led by Valverde, whose presence and action in Doñana is subject to a certain degree of randomness. Moreover, the timing and sequence of the process triggered by Valverde's group, overlapping with the process of agricultural transformation, led to the actual systemic rigidity trap in Doñana, instead of a much more difficult-to-escape lock-in trap (Allison and Hobbs 2004) that would be characterized by a deep erosion of environmental and ecological values (Méndez et al. 2012). In other words, it led to a clash of discourses and developments on the ground that was arguably the result of a certain degree of random chance.

\section{CONCLUSIONS}

The present paper, in combination with the historical pattern of the first theoretical iteration presented in Méndez et al. 2012, seeks to round up a comprehensive story about a complex SES from different disciplinary angles, considering a broad diversity of influencing factors. In this second research iteration, based on our results and discussion, we argue that three mechanisms were necessary and sufficient conditions for the emergence of the Doñana's systemic rigid outcome: (1) a contextual politicaldiscursive mechanism that mobilized power top-down from the constitutional level and signaled increasing returns to actors downstream at the collective-action level; (2) the operation of increasing returns and self-reinforcing mechanisms bottom-up; (3) a dual endogenous institutional entrepreneurial component that acted as a mechanism for action in an environment of extreme uncertainty at the collective-action level. At a theoretical level, our explanatory refinement of the Doñana region's path- dependent historical pattern has shown how its current maladaptive state (rigidity trap) is more expected to occur if a more comprehensive analytical framework is used, in this case, the pIAD. Our study of political, discursive, and power contextual factors, and endogenous entrepreneurial components, has shown how contingency might be turned into a property that can be modulated. In that form, contingency can be used as an instrument to help institutional analysts to avoid premature assessments of historical events as proceeding by chance or localized behavioral dynamics as subject to inherent randomness. More generally, the use of enhanced epistemological devices can warn analysts that upper, structural factors could be affecting decision and action downstream into the local level negatively, contributing to the emergence of undesirable systemic outcomes. This means that our predictive power might be further enhanced through systematic, comparative studies including contextual and local variables or indicators addressing multilevel phenomena so as to account for broader sets of outcomes. Thus, we might increase our capacity to inform future policy and institutional, transitional designs toward more sustainable outcomes in SES, in a more comprehensive and interdisciplinary way.

In these future designs, the discussion of optimality criteria in the context of path dependence and neoclassical economics principles should be made explicit, for two main reasons. On the one hand, neoclassical economics principles obviate, by default, the complex and uncertain dynamics of SES, as well as the role of politics, discourses, and power in the determination of efficiency and optimality standards. Unfortunately, such principles are still uncritically mainstreamed in current policies and institutional designs. On the other hand, path dependence brings a built-in high heuristic power for normative purposes by 
raising concerns with the risk of lock-in of structural components, e.g., technologies, institutions, ideas, paradigms. This is critical in the presence, for example, of large set-up, sunk or transaction costs, resulting in institutional inertia and the irreversibility of changes made to SES biophysical conditions. An improved understanding of current, seemingly random institutional or ecological occurrences would entail the improvement of our present scientific tools. More pragmatically, it would entail an early awareness of behaviors or events that might signal the imminent fall of a given SES into an undesirable outcome bearing high opportunity costs, e.g., lock-in traps. In the Doñana case, we wonder whether changes in the productive elements of discursive factors, e.g., arguments or narratives, could trigger more profound changes in institutional structures that facilitate a transition toward a more adaptive and flexible paradigm, i.e., whether ideas and discourses can contribute to change the institutional architecture of the Doñana SES.

Responses to this article can be read online at: http://www.ecologyandsociety.org/issues/responses. php/10898

\section{Acknowledgments:}

This study was conducted thanks to the financial support of the Doñana 2005 Project (Guadalquivir River Authority, Spanish Ministry of Environment), the European Union Horizon 2020 Research and Innovation Program under grant agreement No. 641762 to ECOPOTENTIAL project, and Newcastle University. We would especially like to acknowledge our debt to James Mahoney, whose integrative work on path dependence greatly stimulated our thinking on the application of the subject of contingency to the Doñana case. Also, we are grateful to Floriane Clement and two anonymous reviewers whose challenging and constructive comments helped to improve our manuscript substantially. A very special thought goes to Elinor Ostrom. Finally, Pablo Fernández Méndez would like to express his gratitude to his family, without whose support his participation on this research would have been improbable. In Memoriam: Inmaculada Méndez Serrano, 1959-2019.

\section{LITERATURE CITED}

Adger, W. N., T. A. Benjaminsen, K. Brown, and H. Svarstad. 2001. Advancing a political ecology of global environmental discourses. Development and Change 32(4):687-715. https://doi. org/10.1111/1467-7660.00222

Allison, H. E., and R. J. Hobbs. 2004. Resilience, adaptive capacity, and the "Lock-in Trap" of the Western Australian agricultural region. Ecology and Society 9(1):3. https://doi. org/10.5751/ES-00641-090103

Armitage, D. 2007. Governance and the commons in a multi-level world. International Journal of the Commons 2:7-32. http://doi. org/10.18352/ijc. 28

Arrow, K. J. 2000. Increasing returns: historiographic issues and path dependence. European Journal of the History of Economic Thought 7:171-180. https://doi.org/10.1080/713765179
Arthur, W. B. 1988. Self-reinforcing mechanisms in economics. Pages 9-31 in P. W. Anderson, K. J. Arrow, and D. Pines, editors. The economy as an evolving complex system. Addison-Wesley, Reading, Massachusetts, USA. https://doi.org/10.1201/9780429492846-2

Arthur, W. B. 1994. Increasing returns and path dependence in the economy. University of Michigan Press, Ann Arbor, Michigan, USA. https://doi.org/10.3998/mpub.10029

Barciela, C. F., and M. I. López. 2003. El fracaso de la política agraria del primer franquismo, 1939-1959. Veinte años perdidos para la agricultura española. Pages 55-94 in C. F. Barciela, editor. Autarquía y mercado negro: el fracaso económico del primer franquismo, 1939-1959. Crítica, Barcelona, Spain.

Beier, C. 2011. Factors influencing adaptive capacity in the reorganization of forest management in Alaska. Ecology and Society 16(1):40. https://doi.org/10.5751/ES-03822-160140

Biermann, F., K. Abbott, S. Andresen, K. Bäckstrand, S. Bernstein, M. M. Betsill, H. Bulkeley, B. Cashore, J. Clapp, C. Folke, et al. 2012. Navigating the Anthropocene: improving Earth system governance. Science 335(6074):1306-1307. http://doi. org/10.1126/science. 1217255

Blomquist, W., C. Giansante, A. Bhat, and K. Kemper. 2005. Institutional and policy analysis of river basin management: the Guadalquivir River Basin, Spain. World Bank Policy Research Working Paper. The World Bank, Washington, D.C., USA. https://doi.org/10.1596/1813-9450-3526

Boonstra, W. J., and de F. W. de Boer. 2014. The historical dynamics of social-ecological traps. Ambio 43(3):260-274. https:// dx.doi.org/10.1007\%2Fs13280-013-0419-1

Boschma, R., and R. Martin. 2010. The handbook of evolutionary economic geography. Edward Elgar, Cheltenham, UK. https://doi. org/10.4337/9781849806497

Brundtland Report. 1987. Our common future. Oxford University Press, Oxford, UK.

Butchart, S. H. M., M. Walpole, B. Collen, A. von Strien, J. P. W. Scharleman, R. E. A. Almond, J. E. M. Baillie, B. Bomhard, C. Brown, J. Bruno, et al. 2010. Global biodiversity: indicators of recent declines. Science 328:1164-1168. http://doi.org/10.1126/ science. 1187512

Castells, M., J. Cruz, E. Custodio, F. García-Novo, J.-P. de Gaudemar, J. L. González, V. Granados, A. Magraner, C. Román, M. Smart, and E. van der Maarel. 1992. Dictamen sobre estrategias para el desarrollo socioeconómico sostenible del entorno de Doñana. Comisión Internacional de Expertos sobre el Desarrollo del Entorno de Doñana, Junta de Andalucía, Seville, Spain. [online] URL: http://www.juntadeandalucia.es/servicios/ publicaciones/detalle/41400.html

Castroviejo, J. 1993. Memoria: Mapa del Parque Nacional de Doñana. Consejo Superior de Investigaciones Científicas y Agencia de Medio Ambiente de la Junta de Andalucía, Madrid, Spain.

Clement, F. 2010. Analysing decentralised natural resource governance: proposition for a "politicised" Institutional Analysis and Development framework. Policy Sciences 43:129-156. https:// doi.org/10.1007/s11077-009-9100-8 
Clement, F., and J. M. Amezaga. 2013. Conceptualising context in institutional reforms of land and natural resource management: the case of Vietnam. International Journal of the Commons 7(1):140-163. http://doi.org/10.18352/ijc.338

Corominas, J. 1995. La agricultura en el entorno de Doñana. Revista de Obras Públicas 142(3340):65-74. [online] URL: http:// ropdigital.ciccp.es/detalle articulo.php?registro=17383\&numerorevista $=3340$ \&anio $=1995$ \&anio ini $=$ \&anio fin $=$

Costa, J. 1911. Política Hidráulica (Misión social de los riegos en España). Apéndice y notas por Fernando Sáenz Ridruejo, Madrid, Colegio de Ingenieros de Caminos, Canales y Puertos, 1975. Biblioteca Joaquín Costa, Madrid, España. https://doi. org/10.5962/bhl.title. 21500

David, P. A. 2007. Path dependence, its critics, and the quest for 'historical economics.' Pages 120-143 in G. M. Hodgson, editor. The evolution of economic institutions: a critical reader. Edward Elgar, Cheltenham, UK. https://doi.org/10.4337/9781847207036.00016

Deeg, R. 2001. Institutional change and the uses and limits of path dependency: the case of German finance. Discussion Paper 01/6. Max-Planck-Institut für Gesellschaftsforschung, Cologne, Germany. http://dx.doi.org/10.2139/ssrn.1013345

Díaz-Marta, M. 1989. Esquema histórico de la ingeniería y la gestión del agua en España. Obras Públicas 13:8-21. [online] URL: http:/hispagua.cedex.es/sites/default/files/hispagua articulo//op/13/ art2/img.htm

Dirzo, R., and P. H. Raven. 2003. Global state of biodiversity and loss. Annual Review of Environment and Resources 28:137-167. https://doi.org/10.1146/annurev.energy.28.050302.105532

Eagle, A. 2005. Randomness is unpredictability. British Journal for the Philosophy of Science 56(4):749-790. https://doi. org/10.1093/bjps/axi138

Enggass, P. M. 1968. Land reclamation and resettlement in the Guadalquivir Delta. Las Marismas. Economic Geography 44:125-143. http://doi.org/10.2307/143310

Fernández, E. 2000. Un siglo de obras hidráulicas en España: de la utopía de Joaquín Costa a la intervención del Estado. Cuadernos de Escuela y Despensa, Facultad de Ciencias Económicas y Empresariales, Zaragoza, España. [online] URL: https://dialnet. unirioja.es/servlet/libro?codigo $=179396$

Fine, B. 2000. New and improved: economics' contribution to business history. SOAS Working Papers in Economics 93:1-16. [online] URL: http://eprints.soas.ac.uk/id/eprint/2339

Foucault, M. 1979. Discipline and punish: the birth of the prison. Penguin, Harmondsworth, UK.

Gil, A. 2001. Del Plan General de 1902 a la planificación hidrológica. Investigaciones Geográficas 25:1-31. https://doi. org/10.14198/ingeo2001.25.03

Gómez-Baggethun, E., and E. Kelemen. 2008. Linking institutional change and the flows of ecosystem services. Case studies in Spain and Hungary. Pages 118-145 in T. KuvánkováOravská, V. Chobotova, J. Jilkova, and P. Sauer, editors. Institutional analysis of sustainability problems. Slovak Academy of Sciences, Bratislava, Slovakia.
Gómez-Baggethun, E., V. Reyes-García, P. Olsson, and C. Montes. 2012. Traditional ecological knowledge and community resilience to environmental extremes: a case study in Doñana, SW Spain. Global Environmental Change 22:640-650. https://doi. org/10.1016/j.gloenvcha.2012.02.005

Gómez-Mendoza, J. 1992. Regeneracionismo y regadíos. Pages 231-262 in A. Gil and A. Morales, editors. Hitos históricos de los regadios españoles. Ministerio de Agricultura, Pesca y Alimentación, Madrid, España.

González-Arteaga, J. 1993. Valencianos y arroz en las marismas del Guadalquivir. Revista de Estudios Andaluces 19:67-95. https:// doi.org/10.12795/rea.1993.i19.05

González-Arteaga, J. 2005. El arroz en las marismas del Guadalquivir. Evolución y problemática actual. Publicaciones de la Universidad de Sevilla, Sevilla, España.

Grande-Covián, R. 1977. El estuario del Guadalquivir y su problemática agraria. Revista de Estudios Agrosociales 101:27-42. [online] URL: https://www.miteco.gob.es/app/publicaciones/ art datos.asp? articuloid $=88 \&$ codrevista $=$ REAS

Gunderson, L. H., C. S. Holling, and S. S. Light. 1995. Barriers and bridges to the renewal of ecosystems and institutions. Columbia University Press, New York, New York, USA.

Haberl, H., M. Fischer-Kowalski, F. Krausmann, J. MartinezAlier, and V. Winiwarter. 2011. A socio-metabolic transition towards sustainability? Challenges for another Great Transformation. Sustainable Development 19(1):1-14. https://doi. org/10.1002/sd.410

Hajer, M., and W. Versteeg. 2005. A decade of discourse analysis of environmental politics: achievements, challenges, perspectives. Journal of Environmental Policy and Planning 7(3):175-184. https://doi.org/10.1080/15239080500339646

Herrfahrdt-Pähle, E., and C. Pahl-Wostl. 2012. Continuity and change in social-ecological systems: the role of institutional resilience. Ecology and Society 17(2):8. https://doi.org/10.5751/ ES-04565-170208

Holling, C. S., and C. R. Allen. 2002. Adaptive inference for distinguishing credible from incredible patterns in nature. Ecosystems 5:319-328. https://doi.org/10.1007/s10021-001-0076-2

Holling, C. S., L. H. Gunderson, and G. D. Peterson. 2002. Sustainability and panarchies. Pages 63-102 in L. H. Gunderson and C.S. Holling, editors. Panarchy: understanding transformations in human and natural Systems. Island Press, Washington, D.C., USA.

Holling, C. S., and G. K. Meffe. 1996. Command and control and the pathology of natural resource management. Conservation Biology 10(2):328-337. https://doi.org/10.1046/j.1523-1739.1996.10020328. $\underline{x}$

Jäger, S., and F. Maier. 2009. Theoretical and methodological aspects of Foucaldian critical discourse analysis and dispositive analysis. Pages 34-61 in R. Wodak and M. Meyer, editors. Methods of critical discourse analysis. SAGE, London, UK.

Jørgensen, M., and L. J. Phillips. 2002. Discourse analysis as theory and method. SAGE, London, UK. https://doi.org/10.4135/9781849208871 
Kay, A. 2005. A critique of the use of path dependency in policy studies. Public Administration 83:553-571. https://doi.org/10.1111/ j.0033-3298.2005.00462.x

Kiser, L., and E. Ostrom. 1982. The three worlds of action: a metatheoretical synthesis of institutional approaches. Pages 179-222 in E. Ostrom, editor. Strategies of political inquiry. SAGE, Beverly Hills, California, USA.

Levin, S. A., and W. C. Clark. 2010. Toward a science of sustainability: report from toward a science of sustainability conference. Airlie Center, Warrenton, Virginia. CID Working Paper No. 196, Center for International Development, Harvard University, Cambridge, Massachusetts, USA. [online] URL: https://ideas.repec.org/p/cid/wpfacu/196.html

Lewis, P. M. 2007. Growing apart: oil, politics, and economic change in Indonesia and Nigeria. The University of Michigan Press, Ann Arbor, Michigan, USA. https://doi.org/10.3998/mpub.206785

Loorbach, D., and J. Rotmans. 2006. Managing transitions for sustainable development. Pages 187-206 in X. Olsthoorn and A. J. Wieczorek, editors. Understanding industrial transformation. Springer, Dordrecht, The Netherlands. https://doi. org/10.1007/1-4020-4418-6 10

López-Gunn, E. 2009. Agua para todos: a new regionalist hydraulic paradigm in Spain. Water Alternatives 2(3):370-394. [online] URL: http://www.water-alternatives.org/index.php/ alldoc/articles/vol2/v2issue3/66-a2-3-5/file

Lukes, S. 2005. Power: a radical view. Second edition. . Palgrave Macmillan, Basingstoke, UK.

Mahoney, J. 2000. Path dependence in historical sociology. Theory and Society 29(4):507-548. [online] URL: https://www.jstor.org/ stable/3108585

Markard, J., R. Raven, and B. Truffer. 2012. Sustainability transitions: an emerging field of research and its prospects. Research Policy 41(6):955-967. https://doi.org/10.1016/j. respol.2012.02.013

Martín-López, B., M. García-Llorente, I. Palomo, and C. Montes. 2011. The conservation against development paradigm in protected areas: valuation of ecosystem services in the Doñana social-ecological system (southwestern Spain). Ecological Economics 70:1481-1491. https://doi.org/10.1016/j.ecolecon.2011.03.009

Mateu, J. J. 2002. Política hidráulica e intervención estatal en España (1880-1936): una visión interdisciplinar. Estudios Agrosociales y Pesqueros 197:35-61. [online] URL: https://dialnet. unirioja.es/servlet/articulo? codigo $=635708$

McCarthy, D. D. P., G. S. Whitelaw, F. R. Westley, D. D. Crandall, and D. Burnett. 2014. The Oak Ridges Moraine as a social innovation: strategic vision as a social-ecological interaction. Ecology and Society 19(1):48. https://doi.org/10.5751/ES-06212-190148

McGinnis, M. D. 2011. An introduction to IAD and the language of the Ostrom workshop: a simple guide to a complex framework. Policy Studies 39(1):169-183. https://doi.org/10.1111/ j.1541-0072.2010.00401.x

Méndez, P. F., N. Isendahl, J. M. Amezaga, and L. Santamaría. 2012. Facilitating transitional processes in rigid institutional regimes for water management and wetland conservation: experience from the Guadalquivir Estuary. Ecology and Society 17(1):26. http://dx.doi.org/10.5751/ES-04494-170126

Millennium Ecosystem Assessment (MEA). 2005. Ecosystems and human well-being: synthesis. Island Press, Washington, D.C., USA.

Moore, M.-L., and O. Tjornbo. 2012. From coastal timber supply area to Great Bear Rainforest: exploring power in a socialecological governance innovation. Ecology and Society 17(4):26. https://doi.org/10.5751/es-05194-170426

Moral-Ituarte, L. 1991. La obra hidráulica en la cuenca del Bajo Guadalquivir (siglos XVIII-XX). Gestión del agua y organización del territorio. Publicaciones de la Universidad de Sevilla, Sevilla, España. https://doi.org/10.12795/9788447220908

Moral-Ituarte, L. 1993. El cultivo del arroz en las Marismas de Doñana: Situación actual y perspectivas. Agricultura y Sociedad 67:205-233

Moral-Ituarte, L. 2009. Changing water discourses in a modern society. Pages 85-93 in A. Garrido and R. Llamas, editors. Water policy in Spain. Taylor and Francis, London, UK.

Muñoz, V. M. 2007. Latifundios, reforma agraria y estructura de la propiedad en los contextos arroceros sevillanos. Anduli 7:143-164. [online] URL: https://dialnet.unirioja.es/servlet/ articulo?codigo $=2737231$

Muñoz, V. M. 2009. Agua, arroz y Doñana: Caminos convergentes. Revista Andaluza de Ciencias Sociales 8:135-151. [online] URL: https://idus.us.es/xmlui/handle/11441/51039

North, D. C. 1981. Structure and change in economic history. W. W. Norton and Co., New York, New York, USA.

North, D. C. 1990. Institutions, institutional change and economic performance. Cambridge University Press, Cambridge, UK. https://doi.org/10.1017/CBO9780511808678

North, D. C. 1991. Institutions. Journal of Economic Perspectives 5(1):97-112. https://doi.org/10.1257/jep.5.1.97

North, D. C. 2005. Understanding the process of economic change. Princeton University Press, Princeton, New Jersey, USA. https:// doi.org/10.1515/9781400829484

Nykvist, B., and J. von Heland. 2014. Social-ecological memory as a source of general and specified resilience. Ecology and Society 19(2):47. http://dx.doi.org/10.5751/ES-06167-190247

Ojeda-Rivera, J. F., and L. Moral-Ituarte. 2004. Percepciones del agua y modelos de su gestión en las distintas fases de la configuración de Doñana. Investigaciones Geográficas 35:25-44. [online] URL: http://hdl.handle.net/10045/289 https://doi. org/10.14198/INGEO2004.35.06

Olsson, P., C. Folke, and T. P. Hughes. 2008. Navigating the transition to ecosystem-based management of the Great Barrier Reef, Australia. Proceedings of the National Academy of Sciences 105(28):9489-9494. https://doi.org/10.1073/pnas.0706905105

Ortega, N. 1984. Las propuestas hidráulicas del reformismo republicano: del fomento del regadío a la articulación del Plan Nacional de Obras Hidráulicas. Agricultura y Sociedad 
32:109-152. [online] URL: https://dialnet.unirioja.es/servlet/ articulo? $\operatorname{codig}_{0}=82602$

Ortí, A. 1984. Política hidráulica y cuestión social: orígenes, etapas y significados del regeneracionismo hidráulico de Joaquín Costa. Agricultura y Sociedad 32:11-107. [online] URL: https:// dialnet. unirioja.es/servlet/articulo? codigo $=82603$

Österblom, H., M. Sissenwine, D. Symes, M. Kadin, T. Daw, and C. Folke. 2011. Incentives, social-ecological feedbacks and European fisheries. Marine Policy 35(5):568-574. https://doi. org/10.1016/j.marpol.2011.01.018

Ostrom, E. 2005. Understanding institutional diversity. Princeton University Press, Princeton, New Jersey, USA. https://doi. org/10.2307/j.ctt7s $7 \mathrm{wm}$

Palomo, I., B. Martín-López, C. López-Santiago, and C. Montes. 2011. Participatory scenario planning for protected areas management under the ecosystem services framework: the Doñana social-ecological system in southwestern Spain. Ecology and Society 16(1):23. https://doi.org/10.5751/es-03862-160123

Paneque, P., and J. Vargas. 2015. Drought, social agents and the construction of discourse in Andalusia. Environmental Hazards 14(3):224-235. https://doi.org/10.1080/17477891.2015.1058739

Pardo, L. 1933. I Plan Nacional de Obras Hidráulicas. Ministerio de Obras Públicas, Centro de Estudios Hidrográficos, Madrid, España.

Parry, S., J. Hannaford, B. Lloyd-Hughes, and C. Prudhomme. 2012. Multi-year droughts in Europe: analysis of development and causes. Hydrology Research 43(5):689-706. https://doi. org/10.2166/nh.2012.024

Peters, B. G., J. Pierre, and D. S. King. 2005. The politics of path dependency: political conflict in historical institutionalism. Journal of Politics 67(4):1275-1300. https://doi.org/10.1111/ j.1468-2508.2005.00360.x

Pierson, P. 2000a. Increasing returns, path dependence, and the study of politics. American Political Science Review 94 (2):251-267. https://doi.org/10.2307/2586011

Pierson, P. 2000b. Not just what, but when: timing and sequence in political processes. Studies in American Political Development 14:72-92. https://doi.org/10.1017/S0898588X00003011

Plan de Ordenación del Territorio del Ámbito (POTAD). 2003. Plan de Ordenación del Territorio del Ámbito de Doñana. Consejería de Obras Públicas y Transportes, Junta de Andalucía, Sevilla. España.

Portero, M. 2001. Cultivo del arroz en el sur de España. El Monte, Caja de Ahorros, Sevilla, España.

Portero, M., L. Navarro, and J. M. García. 2007. Estudio agroeconómico del cultivo del arroz bajo producción integrada en las Marismas del Guadalquivir. Consejería de Agricultura y Pesca, Junta de Andalucía, Sevilla, España.

Pritchard L., Jr., and S. E. Sanderson. 2002. The dynamics of political discourse in seeking sustainability. Pages 147-169 in L. H. Gunderson and C. S. Holling, editors. Panarchy: understanding transformations in human and natural systems. Island Press, Washington, D.C., USA.
Raskin, P., T. Banuri, G. Gallopín, P. Gutman, A. Hammond, R. Kates, and R. Swart. 2002. Great transition: the promise and lure of the times ahead. GTI Paper Series no. 1. Stockholm Environmental Institute, Tellus Institute and Great Transition Initiative, Boston, Massachusetts, USA. [online] URL: http:// www.tellus.org/tellus/publication/great-transition-the-promise-andlure-of-the-time-ahead

Rockström, J., W. Steffen, K. Noone, Å. Persson, F. S. Chapin, III, E. Lambin, T. M. Lenton, M. Scheffer, C. Folke, H. Schellnhuber, B. Nykvist, C. A. De Wit, T. Hughes, S. van der Leeuw, H. Rodhe, S. Sörlin, P. K. Snyder, R. Costanza, U. Svedin, M. Falkenmark, L. Karlberg, R. W. Corell, V. J. Fabry, J. Hansen, B. Walker, D. Liverman, K. Richardson, P. Crutzen, and J. Foley. 2009. Planetary boundaries: exploring the safe operating space for humanity. Ecology and Society 14(2):32. https://doi. org/10.5751/ES-03180-140232

Rubio-Recio, J. M. 1977. Nota sobre la significación biogeográfica y los problemas de las marismas del Guadalquivir y su parque nacional. Cuadernos geográficos de la Universidad de Granada 7:277-292. [online] URL: https://dialnet.unirioja.es/ servlet/articulo?codigo $=1249246 \mathrm{https}: / /$ doi.org/10.1093/ gao/97818844446054.article.t049444

Rubio-Recio, J. M. 1993. Doñana y su entorno: Conservación y explotación. Revista de Estudios Andaluces 19:53-66. https://doi. org/10.12795/rea.1993.119.04

Sabuco, A. 1997. La "colonización" de la Isla Mayor del Guadalquivir: representaciones territoriales y sistemas identitarios. Revista Andaluza de Relaciones Laborales 3:53-70. [online] URL: https://hdl.handle.net/11441/73009

Sánchez, J. C. 1997. Rafael Gasset y la política hidráulica de la Restauración, 1900-1923. Revista de Historia Económica 15 (2):319-362. https://doi.org/10.1017/s0212610900006534

Santamaría, L., C. Montes, and M. J. M. Hootsmans. 1996. Influence of environmental parameters on the biomass development of Ruppia drepanensis populations in Doñana National Park: the importance of conditions affecting the underwater light climate. International Journal of Salt Lake Research 5:157-180. http://dx.doi.org/10.1007/BF01995828

Smith, A., and A. Stirling. 2010. The politics of social-ecological resilience and sustainable socio-technical transitions. Ecology and Society 15(1):11. https://doi.org/10.5751/ES-03218-150111

Steffen, W. L., A. Sanderson, D. Tyson, J. Jäger, P. A. Matson, B. Moore, F. Oldfield, K. Richardson, H.-J. Schellnhuber, B. L. Turner, and R. J. Wasson. 2004. Global change and the earth system: a planet under pressure. Springer-Verlag, New York, New York, USA.

Sumpsi, J. M. 1980. Análisis de las transformaciones económicas y de los sistemas de tenencia en las grandes explotaciones arroceras del Guadalquivir (1940-1975). Revista de Estudios Agrosociales 111:63-121. [online] URL: https://dialnet.unirioja. es/servlet/articulo? codigo $=2196165$

Swyngedouw, E. 1999. Modernity and hybridity: nature, regeneracionismo, and the production of the Spanish waterscape, 1890-1930. Annals of the Association of American Geographers 89 (3):443-465. https://doi.org/10.1111/0004-5608.00157 
Valverde, J. A. 2004. La Aventura de Doñana. Cómo crear una Reserva. Quercus, Madrid, España.

Vergne, J.-P., and R. Durand. 2010. The missing link between the theory and empirics of path dependence: conceptual clarification, testability issue, and methodological implications. Journal of Management Studies 47(4):736-759. https://doi.org/10.1111/ j.1467-6486.2009.00913.x

Voß, J., and B. Bornemann. 2011. The politics of reflexive governance: challenges for designing adaptive management and transition management. Ecology and Society 16(2):9. https://doi. org/10.5751/ES-04051-160209

Westley, F. R., O. Tjornbo, L. Schultz, P. Olsson, C. Folke, B. Crona, and Ö. Bodin. 2013. A theory of transformative agency in linked social-ecological systems. Ecology and Society 18(3):27. https://doi.org/10.5751/ES-05072-180327

Woerdman, E. 2004. The institutional economics of market-based climate policy. Elsevier B.V., Amsterdam, The Netherlands.

Yin, R. K. 2009. Case study research: design and methods. Fourth Edition. SAGE, Thousand Oaks, California, USA.

Young, O. R. 2010. Institutional dynamics: resilience, vulnerability and adaptation in environmental and resource regimes. Global Environmental Change 20(3):378-385. https://doi. org/10.1016/j.gloenvcha.2009.10.001 


\section{Appendix 1. Definitions}

\section{The Institutional Analysis and Development framework}

The original Institutional Analysis and Development (IAD) framework (Kiser and Ostrom 1982, Ostrom 2005) focuses the analysis on the relationship among institutions, cultural attributes, biophysical conditions and human behavior and action (Fig. A1.1). Broadly speaking, within the IAD institutional arrangements are understood as "the rules used by individuals for determining who and what are included in decision situations, how information is structured, what actions can be taken and in what sequence, and how individual actions can will be aggregated into collective decisions"; institutions are thus "complex composites of rules, all of which exist in a language shared by some community of individuals rather than as the physical parts of some external environment" (Kiser and Ostrom 2000:56). Based on this approach, institutions are here operationally defined as: the humandevised regular patterns of constraints or opportunities within which the choices, actions and interactions of actors (individual or organizational) take place and which shape the consequences of such choices, actions and interactions - in short, the formal and informal rules of the game (based on North 1990a, Ostrom 2005, McGinnis 2011).

The focal level of analysis of the IAD is the 'action arena' (Fig. A1.1), defined here as the social space where: (1) policies or institutions are designed by 'actors' engaged in action situations ${ }^{1}$ affected by the 'biophysical conditions' and by two social variables reflecting the most substantive part of a pre-existing institutional framework, namely, 'rules-in-use' and 'attributes of the community'; (2) the patterns of interactions and decisions that take place within the action situations shape certain outcomes; (3) such outcomes feedback into the action arena and into the mentioned variables, and may change the institutional framework (Ostrom 2005, McGinnis 2011).
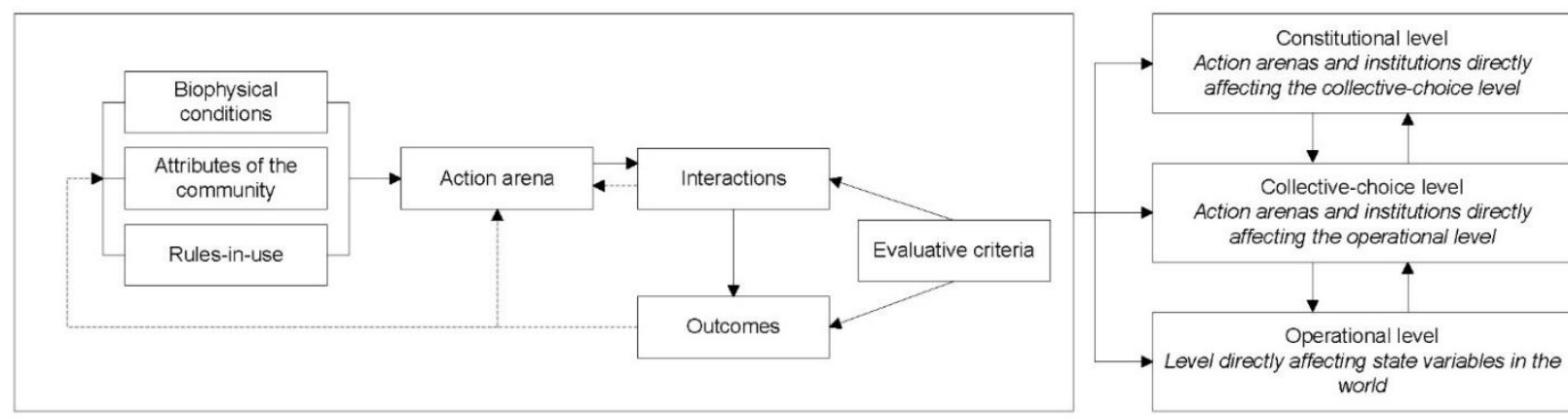

Fig. A1.1. The Institutional Analysis and Development framework. Source: modified from McGinnis (2011)

In sum, actors use institutional prescriptions to organize repetitive and structured interactions while participating in action situations within the action arenas. Institutions are considered as an exogenous variable of the arena, the other exogenous variables being the biophysical system being acted upon and the cultural attributes of the community. Regarding actors, the IAD depicts them as "fallible learners" (McGinnis 2011), i.e. as operating under uncertainty, and having limited cognitive and

\footnotetext{
${ }^{1}$ According to McGinnis (2011:172), originally, "the action situation was enclosed within an action arena, which also included the set of actors as a separate component; however, since the capabilities of actions can be attributed to the effect of the position rules defined below, E. Ostrom (2010) recommends abandoning this distinction between action situation and arena". Here, we keep the original formulation of the action arena, since it better addresses the systemic needs of the present research. In particular, it globally captures the diversity of combinations of rules, situations and actors that can emerge at the different levels of analysis defined by the IAD, namely: constitutional, collective-choice and operational.
} 
information-processing capability (bounded rationality), but as being able of learning from error (adaptive learning). This view of the actor, in particular, "bounded rationality" (Simon 1955), is reactive to the view of rationality as optimization of neoclassical economics. Finally, the IAD device poses a multi-layered hierarchical structure of three tiers for organizing institutional analysis, termed 'constitutional', 'collective choice' and 'operational' (McGinnis 2011). These levels constitute a hierarchical, multi-level structure, in which each upper tier determines how institutions and decisions are made at the next, downward level. The lower levels can, in turn, exert an influence over the upper levels. The lowest, operational level directly affect state variables in the world (see e.g., Ostrom 2005:59).

In this research, the definition of institutions used (see main text) is applied to the variable 'rules-inuse' of the IAD. 'Actors' are considered either as individuals acting on their own or as agents of 'organizations'. In turn, organizations constitute specific ensembles of individuals with common interests, values or beliefs whose formation respond to the institutional framework, or to other constraints or opportunities such as technology or biophysical conditions (based on North 1990a:73, see also North 1990b). We are here therefore differentiating between institutions (e.g., rules, norms) and organizations (e.g., research and management agencies; see also Ostrom 2005:179). With respect to the levels of analysis, the collective-choice and operational levels were combined into a single unit labelled 'collective-action' (see Fig A1.1. See also Fig. 1 in main text), conceptualized as the level directly affecting state variables of the 'biophysical conditions', in our case, Doñana's hydroecological system. This constituted an ad hoc artifact to simplify analysis and discussion, as well as future processes informing both normative transitional designs towards sustainability and future treatments of our unit of analysis in deeper institutional analyses. At a theoretic-analytical level, our research follows Ostrom's (2005:28) prescription to differentiate between the use of theory and analytical frameworks. While the former causally link observed or modelled phenomena providing analysts with interpretive structure, the latter provides analysts with general sets of factors and relationships that must be considered in a diversity of institutional settings.

\section{The concept of path dependence}

Path dependence is used interchangeably as a theory, concept, model or heuristic in the literature. We use it here as a concept that is part of a broader theory, with potential use as both a heuristic and a model, at the discretion of the analyst. Contemporary work on path dependence is rooted in the works of Paul David (e.g., David 1985, 1994) and Brian Arthur (e.g., Arthur 1989, 1990) on the economic history of technology and on self-reinforcing economic processes, respectively. Broadly speaking, the concept challenges one of the main assumptions made by neoclassical theory namely: that technological and economic action always move towards optimal solutions or designs (i.e. outcomes) that are the most efficient in whatever type of function they are argued to fulfill -measured, for example, by Pareto optimality criteria. This assumption stems from the more general assumption that economic action is characterized ex ante by the existence of movements towards a hypothetical, static and invariant general equilibrium. The latter is demonstrated through highly abstract, simplified and idealized market models and solutions, looking at how changes in certain variables (e.g., market prices) affect the equilibrium of other quantities (e.g., other market prices). Inefficient conditions and outputs are envisaged as transitory phenomena, and notions of dynamics, are restricted to movements towards equilibrium, which, once reached, leads to stasis. According to this approach, the outcome is predetermined and independent of how the initial conditions and the history of technological or economic development unfolded over past time, i.e. it is path independent, and the role of history and evolution can be disregarded. The process is arguably complex and context specific, but economic 
action, in general, is assumed to be subject to certain negative-feedback mechanisms (e.g., decreasing returns, competitive pressures, price signals) that offset major changes by reaction and lead the setting, in a linear fashion, towards the predicted optimal equilibrium. Institutions are envisaged as arrangements exogenous to the technological or economic process and their development as driven by a constant, rational search for efficiency by actors seeking to improve their individual welfare, thereby arriving at mutually beneficial, collective outcomes.

The studies on the path dependence of technologies and the economy constitute the core of a much more ample critique to the abstract, and rather normative, principles of neoclassical economics. According to this approach, in the absence of exogenous shocks, lock-in will occur on any alternative sub-optimal outcome that diverge from and select out optimal and more efficient, superior alternatives. The main assumption is that outcomes depend on how the initial conditions and the history of technological or economic development unfold over time, because a multiplicity of multiple-stable equilibria or attractors, defined by limiting probability distributions, exist at the end of the process. Optimal outcomes form part of the range of multiple attractors, but they are not predetermined, for the process is considered as non-ergodic and independent of the level of consciousness or rationality of the actors -which contrast to the insight of not predetermined optimal outcomes as a consequence of the non-existence of fully knowledgeable and rational actors in the 'real' world. In general, it is argued that the beginning of the process is affected by seemingly small, random events that have an unexpected disproportionate effect on the process (i.e. non-linearity), making it unfold in a stochastic fashion. While in the equilibrium approach the assumed mechanisms decrease the probability of distancing from the predetermined optimal outcome, path dependence entails that the probability of occurrence of the sub-optimal outcome increases at each step of the process. This happens owing to 'increasing returns', which deal with the notion of how decisions by actors favoring certain choices (e.g. technology) directly or indirectly increase their attractiveness for other actors, in terms of pay-off or utility. Underlying increasing returns, there are 'self-reinforcing mechanisms', i.e. positive feedback mechanisms that result in a self-reinforcing pattern (e.g., learning and coordination effects).

Sources consulted include: David (1985), Arthur (1989), Arthur (1990), Liebowitz and Margolis (1990), North (1990a), David (1994), Ikenberry (1994), Hacker (1998), Mahoney (2000), Pierson (2000a), Pierson (2000b), David (2007), Arias and Caballero (2003), Puffert (2004), Schwartz (2004), Woerdman (2004), Sydow et al. (2005), Page (2006), Lewis (2007), Boschma and Martin (2010), Vergne and Durand (2010), Dobusch and Schüßler (2012).

\section{Contingency: an epistemological paradox}

In this research, we are concerned with a specific epistemological tension between two senses of contingency, as established by Mahoney (2000:513): (1) the "inability of theory to predict or explain, either deterministically or probabilistically, the occurrence of a specific outcome", hence a contingent event is "an occurrence that was not expected to take place, given certain theoretical understandings of how causal processes work"; (2) that some events or behaviors are part of a "non-systematic variation inherent in the world that cannot even in principle be eliminated from causal theories". Generally speaking, any event, behavior or outcome at odds with analysis is assessed as contingent because it appears as either unforeseen by the set of general principles or propositions of the epistemological device at work (e.g., analytical framework, theory, model), or random phenomena of an inherently stochastic world (e.g., chance, freewill, agency, natural disasters). 
And herein lies the paradox. According to Mahoney (2000:516), the combination of the indeterminism characterizing contingency in the genetic phases (e.g., critical junctures) with the determinism of the mechanisms leading to the reproduction of the outcome in a self-reinforcing pathdependent sequence, lead to a paradox, since such outcome simultaneously: (1) contradict the analytical framework at work; (2) is reproduced through mechanisms associated with the contradicted framework. Although Mahoney (2000) speaks generally about prevailing analytical frameworks and different disciplines, he exemplifies about the path dependence of technologies or the economic process and their organizations (e.g., QWERTY vs. Dvorak keyboards, mass vs. craft production). There, the outcome is assessed as contingent because it appears to contradict the principles of neoclassical economics. Broadly speaking, the efficiency of technologies, economies or institutions is called into question in an assessment against the principles of models portraying an ideal world in which optimality is achieved in a state of equilibrium. To make sense of the paradox, Mahoney argues, it must be recognized that (1) the outcome results contradictory when it is compared with past alternatives, which were viable at the earliest part of the path-dependent historical sequence and, from a neoclassical standpoint, seemed as more efficient and optimal choices; and (2) although a suboptimal, far-from-equilibrium and inefficient outcome is produced instead, such outcome is reproduced at present by neoclassical-theory mechanisms. In other words, the key of this seeming paradox lies in that explanations about the lock-in phase rely on the same, negative feedback mechanisms associated with neoclassical theory (e.g., constant or decreasing returns), which are contradicted by what is occurring at the initial (e.g., randomness, unpredicted or illogical behavior) and self-reinforcement (e.g., increasing returns) phases, i.e. by actual events or behaviors. In the institutional realm, this focus on neoclassical economics, in particular, on its utilitarian core, results in a failure to theorize different mechanisms explanatory of institutional dynamics (Mahoney 2000:525-526).

Here, we would like to emphasize a higher implication of this paradox at an epistemological level, with both theoretical and normative repercussions. The two significations identified by Mahoney are two attributes representing two extremes of contingency, one referring to pure randomness or chance, and another, to pure predictability (after Eagle 2005). Between both, a continuum of predictability unfolds, with randomness equating a high level of unpredictability. This approach neither preclude the existence of regularities in sequences of events with uncertain outcomes, nor exclude the possibility to describe certain outcome phenomena or evolution of events through probability distributions. Since events or behaviors that are observed as random or unexpected under certain epistemological devices might be straightforwardly explicable or predicted by alternative devices, randomness might reveal and be more properly assessed as unpredictability to some degree. In other words, that the outcome under analysis is assessed as contingent by certain theoretical notions, doesn't mean that its emergence cannot be consistent with the expectations of alternative theories positing causal links accounting for such outcome.

\section{LITERATURE CITED}

Arias, X. C., and G. Caballero. 2003. Instituciones, costos de transacción y políticas públicas: Un panorama. Revista de Economía Institucional 5(8):117-146. [online] URL: https://dialnet.unirioja.es/servlet/articulo?codigo=2329137

Arthur, B. W. 1989. Competing technologies, increasing returns and lock-in by historical events. Economic Journal 99:116-131. http://doi.org/10.2307/2234208 
Arthur, B. W. 1990. Positive feedbacks in the economy. Scientific American 262:92-99. http://www.jstor.org/stable/24996687

Boschma, R., and R. Martin. 2010. The handbook of evolutionary economic geography. Edward Elgar, Cheltenham, UK.

David, P. A. 1985. Clio and the economics of QWERTY. American Economic Review Proceedings 75:332-337. https://ideas.repec.org/a/aea/aecrev/v75y1985i2p332-37.html

David, P. A. 1994. Why are institutions the "carriers of history"? Path dependence and the evolution of conventions, organizations and institutions. Structural Change and Economic Dynamics 5:205220. https://doi.org/10.1016/0954-349X(94)90002-7

David, P. A. 2007. Path dependence, its critics, and the quest for 'historical economics.' Pages 120 143 in G. M. Hodgson, editor. The evolution of economic institutions: a critical reader. Edward Elgar, Cheltenham, UK.

Dobusch, L., and Schüßler, E. 2012. Theorizing path dependence: A review of positive feedback mechanisms in technology markets, regional clusters, and organizations. Industrial and Corporate Change 1-31. https://doi.org/10.1093/icc/dts029

Eagle, A. 2005. Randomness is unpredictability. British Journal for the Philosophy of Science 56(4):749-790. https://philpapers.org/rec/EAGRIU

Hacker, J. S. 1998. The historical logic of national health insurance: Structure and sequence in the development of British, Canadian, and U.S. medical policy. Studies in American Political Development 12:57-130.

Ikenberry, G. J. 1994. History's heavy hand: institutions and the politics of the state. Presented at the Conference on The New Institutionalism. University of Maryland, October 14-15, 1994. [online] URL: https://scholar.princeton.edu/gji3/publications/historys-heavy-hand

Kiser, L., and E. Ostrom. 1982. The three worlds of action: A metatheoretical synthesis of institutional approaches. Pages 179-222 in E. Ostrom, editor. Strategies of political inquiry. Sage, Beberly Hills, USA.

Kiser, L., and E. Ostrom. 2000. The three worlds of action: A metatheoretical synthesis of institutional approaches. Pages 56-88 in M. D. McGinnis, editor. Polycentric games and institutions: Readings from the Workshop in Political Theory and Policy Analysis (Institutional Analysis). The University of Michigan Press, Ann Arbor, USA.

Lewis, P. 2007. Growing apart: Oil, politics and economic change in Indonesia and Nigeria. The University of Michigan Press, Ann Arbor, USA.

Liebowitz, S. J., and S. E. Margolis. 1990. 'The fable of the keys'. Journal of Law and Economics 33(1):1-25. https://www.jstor.org/stable/725509 
Mahoney, J. 2000. Path dependence in historical sociology. Theory and Society 29(4):507-548. https://www.jstor.org/stable/3108585

Mcginnis, M. D. 2011. An introduction to IAD and the language of the Ostrom workshop: A simple guide to a complex framework. Policy Studies 39(1):169-183. https://doi.org/10.1111/j.1541$\underline{0072.2010 .00401 . x}$

North, D. C. 1990a. Institutions, institutional change and economic performance. Cambridge University Press, Cambridge, UK.

North, D.C. 1990b. Institutions and their consequences for economic performance. Pages 383-401 in K. S. Cook and M. Levi, editors. The limits of rationality. Chicago University Press, Chicago, USA.

Ostrom, E. 2005. Understanding institutional diversity. Princeton University Press, New Jersey, USA.

Page, S. E. 2006. Path dependence. Quarterly Journal of Political Science 1:87-115. http://dx.doi.org/10.1561/100.00000006

Pierson, P. 2000a. Increasing returns, path dependence, and the study of politics. American Political Science Review 94(2):251-267. https://doi.org/10.2307/2586011

Pierson, P. 2000b. Not just what, but when: Timing and sequence in political processes. Studies in American Political Development 14:72-92. https://doi.org/10.1017/S0898588X00003011

Puffert, D. J. 2004. Path dependence, network form, and technological change. Pages 63-95 in T. W. Guinnane, W. A. Sundstrom and W. C. Whatley, editors. History matters: Economic growth, technology, and population. Standford University Press, Standford, USA.

Schwartz, H. 2004. Down the wrong path: Path dependence, increasing returns, and historical institutionalism. Mimeo, University of Virginia: Department of Politics. [online] URL: http://www.people.virginia.edu/ hms2f/Path.pdf

Simon, H. A. 1955. A behavioural model of rational choice. The Quarterly Journal of Economics 69(1):99-118. https://www.jstor.org/stable/1884852

Sydow, J., G. Schreyögg, and J. Koch. 2005. Organizational Paths: Path Dependency and Beyond. 21st EGOS Colloquium. Berlin, June 30 - July 2 2005. [online] URL: http://citeseerx.ist.psu.edu/viewdoc/citations?doi=10.1.1.321.6819

Vergne, J-P., and R. Durand. 2010. The missing link between the theory and empirics of path dependence: Conceptual clarification, testability issue, and methodological implications. Journal of Management Studies 47(4):736-759. https://doi.org/10.1111/j.1467-6486.2009.00913.x

Woerdman, E. 2004. The institutional economics of market-based climate policy. Elsevier B.V., Amsterdam, The Netherlands. 


\section{Appendix 2. Historical profile}

Table A2.1. Historical profile - includes only the period comprised between 1870 and the 1990 s (IR = increasing-returns, $\mathrm{SR}$ = self-reinforcement)

\begin{tabular}{|c|c|c|c|}
\hline Phase & Period & Date & Institutional element (legislation, plan, organization) \\
\hline \multirow[t]{3}{*}{ IR } & $\begin{array}{l}\text { Restoration } \\
(1874-1931)\end{array}$ & $1870^{\mathrm{a}}$ & $\begin{array}{l}\text { Royal Order, promoting drainage engineering projects at the Lebrija marshes (left- } \\
\text { bank). Most of the projects were finished in 1928, due to inadequate planning } \\
\text { and the priority given to navigation policies }\end{array}$ \\
\hline & & 1870 & $\begin{array}{l}\text { Canals and Reservoirs Act, granting perpetuity rights to large public-works } \\
\text { companies on the use of infrastructures in which they had invested }\end{array}$ \\
\hline & & 1877 & $\begin{array}{l}\text { Public Works Act, conceiving Hydraulic Plans as a centralization instrument, but } \\
\text { also laying the foundations for sectoral and secondary legislation incentivizing } \\
\text { the private initiative through the Concession/Contract of Public Works. Wetlands } \\
\text { drainage perceived as a cleaning and public health task }\end{array}$ \\
\hline
\end{tabular}

1877 Royal Order, granting the first large-scale drainage works at the Gallega marsh (Aznalcázar; failed and reinstated in 1910) and the marshes of Almonte (not executed), both at the right bank. Projects justified on agricultural development and the fight against the harmful effects of swampy areas

1878 Royal Order (leprosy RO), wetlands as a source of disease and unhealthy areas

1879 Water Act, giving priority to irrigation agriculture through public intervention, over navigation, at the State level - end of laissez-faire policies. Already marked by regenerationist ideas. Recognition of the principle of subsidiarity. Declaration of surface water as a public good. Distinction between continental (e.g., lakes, lagoons; public property) and coastal waters (e.g., marshes, marshy lands; private property). Consideration of few options for water allocation, the most important being drinking water -"agua de boca"-, agricultural and industrial (agricultural mills and sawmills). Decision about the advisability of transformation entrusted to private owners, except when area declared unhealthy by public authorities, which subsequently incentivized transformation (e.g., subsidies, transfer of property or exploitation rights, fiscal exemptions)

1880s Emergence of the hydraulic-irrigation regenerationist discourse (HIR discourse)

1883 Irrigation Act (Gamazo Act), continuing the legislative trend of the Water Acts of 1866 and 1879. Regenerationist

1899 Draft of General Plan of Reservoirs and Irrigation Canals, precursor of the plan of 1902. Backed by the Civil Engineering Corps

1901 Creation of the Hydrologic-Forestry Service and the Hydraulic Works Divisions, precursors of the Water Authorities (1926). In charge of the elaboration of the plan of 1902

1902 General Plan of Irrigation Canals and Reservoirs (GPICR, plan of Rafael Gasset, revised in 1909, 1916 -second Gasset plan-, 1919 and 1922, reducing substantially the initial plan in terms of total irrigable surface). Included novel knowledge about Spanish geography and hydrography, complemented the newly created Hydrologic-Forestry Service, and promoted State interventionism. Elaborated by a team of civil engineers, directed by Rafael Gasset (Ministry of Agriculture, Industry, Trade and Public Works), during more than two years, based upon more than 300 reports elaborated by the Hydraulic Works Divisions. Planning the conversion into irrigable lands of more than 1,460,000 ha (6\% of the total Spanish territory, 296 hydraulics works listed as advisable). Despite its provisional character, it was in force until the creation of the Hydrographic Union Confederations (1926) 
Table A2.1 (continued)

\begin{tabular}{llll}
\hline \hline Phase & Period & Date & Institutional element (legislation, plan, organization) \\
\hline IR & $\begin{array}{l}\text { Restoration } \\
(1874-1931)\end{array}$ & 1907 & $\begin{array}{c}\text { Inner Colonization and Repopulation Act, halting emigration and promoting the } \\
\text { cultivation of low-yield lands. Creation of the Institute of Social Reform }\end{array}$
\end{tabular}

1911 Irrigation of Large Areas Act (Gasset Act), establishing the State as the financer and promoter of large public works. Legislative protection of the plan of 1902. Synergy with the hydro-electric sector, which continued all along the dictatorship of Primo de Rivera and the II Republic. In 1912 there was an extension of aids for large irrigation infrastructures (e.g., special exemptions "franquicias especiales")

1918 Act for the Drainage of Lagoons, Marshes and Marshy Areas (Cambó Act), authorizing the transformation of unproductive lands. Empowerment of regenerationist policies in the primary sector. Included an extensive typology of marshlands and wetlands. Minimum surface liable to be transformed: 100 ha. Large diversity of financial instruments, tax reductions and transfer rights for both public and private actors. Not mandatory to justify investments upon cleaning and purification purposes

1921- Several attempts by private companies, backed by international investment funds

1937 and authorized by regulations, to transform the marshes for farming and agricultural purposes, for example: Guadalquivir Marshes Company (Guadalquivir marshes, 1921); Guadalquivir Islands Company PLC vulgarly known as "the company of the Englishmen", with English and Swiss capital (Isla Mayor, marshes of Aznalcázar and Isla Mínima, right bank, 1926); Company for the Valuation of the Marshes PLC with Argentinean capital (1932); Isla Mayor of Guadalquivir Company PLC (Gallega marsh, right bank, 1934)

Attempts were mostly driven by speculation on the potential of the marshlands for agriculture and in some cases produced high yields, but ended in broad financial and technical failure due to: low profitability of crops in saline soils, fragmentary planning and lack of coordination, and underestimation of damages produced by seasonal natural flooding (e.g., construction of a superficial drainage system incapable of protect agricultural lands) and the harshness of the saline soils (e.g., failure to bring in enough water to effectively washout salts)

1926 Creation of the Water Union Confederations, the modern water authorities

1927 Creation of the Guadalquivir River Authority

1929 General Plan of Public Works of the Guadalquivir Water Union Confederation, operative until the 1970s. Emphasis on the need to regulate and streamline irrigation activities all over the basin through reservoir control

1930 Plan for the Expansion of Irrigation in the Low Guadalquivir (122,750 ha)

IR II Republic 1932 (1931-1939)

Shift Civil War

$1937-$

IR-SR (1936-1939)
Agrarian Reform Act, banning land owners from expelling land tenants from rented lands. Obligation to cultivate, in order to avoid confiscation. Creation of the Institute of Agrarian Reform

Irrigation Act, increasing the State responsibilities in the development of secondary and complementary public works, in order to realize the functioning of the areas already transformed into irrigable lands

National Plan of Hydraulic Works (plan of Lorenzo Pardo), authorized by the Irrigation Act of 1932. Elaborated by the General Directorate of Hydraulic Works, through the creation of a Centre for Hydrographic Studies. The main goal was the correction of the "hydrologic imbalance" of the Iberian Peninsula, with a focus on the south-western ("Levante") territories, whose soils were considered to be productive enough to increase agricultural exports. The need for large water diversions ("trasvases") became institutionalized

First small-scale successes in rice cultivation in "Isla Mayor" and "Isla Mínima" (right bank) by the company of Rafael Beca 
Table A2.1 (continued)

\begin{tabular}{llll}
\hline \hline Phase & Period & Date & Institutional element (legislation, plan, organization) \\
\hline SR & $\begin{array}{l}\text { Dictatorship } \\
\text { of Franco } \\
(1939-1975)\end{array}$ & $\begin{array}{l}1939- \\
1949\end{array}$ & $\begin{array}{l}\text { Battery of regulations further protecting the traditional colonization-and- } \\
\text { development strategy of the state. 1939 - Colonization of Large Areas Act. } \\
\text { Creation of the National Institute of Colonization. Drainage and transformation } \\
\text { of wetlands planned and executed between the mentioned institute and private } \\
\text { actors. Complemented in 1946 by the Local Colonizations of Interest and } \\
\text { Forceful Expropriation of Rustic Property Act }\end{array}$ \\
& & &
\end{tabular}

1939 National Plan of Hydraulic Works (plan of Alfonso Peña), operative until 1963. Synthesized the main principles of the plan of 1933. Complemented by the previous Colonization Act and by another providing aids for irrigation

1940 Declaration of the Guadalquivir marshes as being of National Interest by the National Institute of Colonization. Socioeconomic orientation of the already polderized land (left bank) towards irrigated agriculture

1940s First large-scale successes in rice cultivation by the company Rafael Beca \& Co, Agricultural Industries PLC

1940- Construction of the Low Guadalquivir Canal, declared of National interest, in order

1951 to irrigate the left-bank marshes. Key in the washing of salts from the land, but of no practical use and considered as "dead", at the time of construction, over a stretch beyond a point $80 \mathrm{~km}$ downstream of its beginning, owing to its malfunction in water transport and distribution. It currently forms part of the (more functional) irrigation system of the Low Guadalquivir area (left-bank marshes, 65,000 ha)

1944- 1944-1956 - Canalization and diversion, by Rafael Beca \& Co, Agricultural 1960s Industries PLC, of two of the main channels inflowing into the right-bank marshes: Guadiamar channel, through the Entremuros canal (1 km wide; Fig. 2, point A), and Brazo de la Torre (Fig. 2, point B). The former is currently connected to the second, a dead arm-river that drains to the Guadalquivir Estuary. Construction of about $100 \mathrm{~km}$ of dikes and drains. Protection of 20,000 ha of pastures. The works were supported by the Guadalquivir River Authority and backed by the Gasset Act of 1911. In the 1960s, a dam transverse to Entremuros, towards El Rocío was constructed, which currently constitutes the northern limit of the Doñana Nature Reserve. Most of these works were executed by public contract and publicly funded

1949 Colonization and Property Distribution of Irrigable Areas Act, prompting the transformation of vast areas. Transformation decided, financed and executed by the state. Continual of the Acts of 1939 and 1946

1955 Declaration of the left-bank marshes of National Interest. 65,000 ha $(33,000$ ha of marshes; 32,000 ha of sands)

1953 Improvable Estates Act, classifying large estates either into "improvable" or "model" farms. Classification into "improvable" farm required owners to carry out improvements on pain of compulsory acquisition by the government, in order to increase productivity and qualify such farms as "model"

1960 Irrigation Plan of the Low Guadalquivir (55,000 ha). Construction of a drainage network in the North of Section III (left-bank)

1965- Guadalquivir-FAO Project, carried out by the Spanish Ministries of Industry,

1971 Agriculture and Public Works (IGME, IRYDA), with the technical and financial support of FAO. Discovery of an aquifer suitable for irrigation, located, in part, below the right-bank marshes of Almonte, Hinojos and Aznalcázar (5-14 m deep; 7,000 $\mathrm{hm}^{3}$ ). Backed by the FAO-Guadalquivir project and the experiences of the left-bank, realization of a second hydrological study affecting 23,589 ha, declared of National Interest in 1971. Of these, 6,132 ha were included in a plan for the transformation of the marshes of Almonte, Hinojos and Aznalcázar into irrigated agricultural land (Almonte-Marismas Plan) 
Table A2.1 (continued)

\begin{tabular}{llll}
\hline \hline Phase & Period & Date & Institutional element (legislation, plan, organization) \\
\hline SR & $\begin{array}{l}\text { Transition to } \\
\text { democracy } \\
(1975-1982)\end{array}$ & 1983 & $\begin{array}{l}\text { Water Act, subordinating large water diversions to specific legislation and to future } \\
\text { Hydrologic Plans, and creating the opportunity for an open water market. } \\
\text { Inclusion of underground water in the Hydraulic Public Domain }\end{array}$ \\
SR & 1990s & 1993 & $\begin{array}{l}\text { First draft of a Hydrologic Plan at the national level promoting a new 'hydrological } \\
\text { paradigm' (water supply management) in the 1990, which nevertheless waxed } \\
\text { lyrical over the regenerationist dream of Joaquín Costa and kept a hydraulic mark } \\
\text { in its promotion of large water diversions }\end{array}$ \\
\hline
\end{tabular}

Sources: own elaboration based on the primary and secondary sources used in main text, and on the historical profile elaborated by Méndez et al. (2012). Other secondary sources included (see references below): Andrés-Gallego (1981), Bartolomé (2011), Bayán and Dolz (1995), Ceballos (2001), García and Marín (2006), Gil (2002), Liceras (1987), Rodríguez-Cárdenas (1994)

\section{LITERATURE CITED}

Andrés-Gallego, J. 1981. Revolución y Restauración 1868-1931. Historia General de España y América (XVI-1). RIALP, Madrid, España.

Bartolomé, I. 2011. ¿Fue el sector eléctrico un gran beneficiario de la Política Hidráulica anterior a la guerra civil (1911-1936)? Hispania, Revista Española de Historia 239:789-818. [online] URL: http://hispania.revistas.csic.es/index.php/hispania/article/view/360

Bayán, B., and J. Dolz. 1995. Las aguas superficiales y la marisma del Parque Nacional de Doñana. Revista Obras Públicas 3340:17-29. [online] URL: http://ropdigital.ciccp.es/detalle_articulo.php?registro=17380\&anio=1995\&numero_revista=3340

Ceballos, M. 2001. La problemática jurídico-administrativa de las zonas húmedas. Humedales Mediterráneos 1:155-162. http://www.sehumed.es/banco/archivos/Sehumed_19_colecc155.PDF

García, F., and C. Marín, editors. 2006. Doñana, water and biosphere. Doñana 2005 Project. Guadalquivir River Authority, Ministry of Environment, Madrid, España. [online] URL: https://portals.iucn.org/library/node/46194

Gil, A. 2002. De los planes hidráulicos a la planificación hidrológica. Pages 11-44 in A. Gil and A. Morales, editors. Insuficiencias hídricas y plan hidrológico nacional. Caja de Ahorros del Mediterráneo and Instituto Universitario de Geografía de la Universidad de Alicante, Alicante, España.

Liceras, A. 1987. El I.N.C. instrumento de la política agraria en la era de Franco. Cuadernos geográficos de la Universidad de Granada 16-17:57-78. https://dialnet.unirioja.es/servlet/articulo?codigo $=53179$

Méndez, P. F., N. Isendahl, J. M. Amezaga, and L. Santamaría. 2012. Facilitating transitional processes in rigid institutional regimes for water management and wetland conservation: experience from the Guadalquivir Estuary. Ecology and Society 17(1): 26. http://dx.doi.org/10.5751/ES-04494$\underline{170126}$

Rodríguez-Cárdenas, M. 1994. Historia de la Isla Mayor del Guadalquivir (Desde su formación hasta nuestros días). Florentina Bou, Sevilla, España. 


\section{Appendix 3. Synthesis of the historical pattern}

This appendix includes a synthesis of the historical pattern in the form of links that connect with our arguments in Results and discussion from main text. For greater detail on the explanation and interpretation provided by the historical pattern please see Méndez et al. (2012).

\section{Link 1}

Prior to the $19^{\text {th }}$ century, the Guadalquivir marshlands $(140,000$ ha) were characterized by a subsistence, pre-market economy organized around ancient property arrangements, and farming, fishing and hunting activities. Those activities were of marginal importance due to the constraints imposed by the harsh and inhospitable environment (e.g., strong flood seasonality, water scarcity for human uses, hard climate, soil salinity, unhealthy conditions and risk of malaria). The marshlands endured almost unmodified until the 1920s. However, the first meander cuts and bottom dredging in the estuary (1795-1816) for enhancing navigability and preventing hazardous floods, triggered (Fig. $\left.3, t_{0 A}\right)$ a multi-level process of policy, institutional and strategic change that eventually led to the intensive agricultural and floodplain developments of the second and last thirds of the $20^{\text {th }}$ century. In a first phase (Fig. $3, t_{1 A^{-}} t_{2 A}$ ), the majority of changes occurred in policy and regulations at the constitutional level, and in strategic, property and organizational re-arrangements among actors at the collective-action level. During the 1920s and 1930s, until 1937, this process produced significant agronomic outputs in recurrent attempts by private initiatives, rather innovative for the time (Table A2.1, Appendix 2). In a second phase (Fig. 3, $\mathrm{t}_{2 \mathrm{~A}}-\mathrm{t}_{3 \mathrm{~A}}$ ), between 1937 and the $1980 \mathrm{~s}$, the process produced changes at multiple regime levels, the most significant being the massive transformation that took place on the ground, in three waves. On the one hand, two concurrent waves of land transformation took place in both the left and right banks of the estuary (1937-1980s): one led to the implementation and development of rice agriculture; and the other, which followed closely, led to the development of irrigation agriculture. On the other hand, an inward-outward protection-forconservation race of the Doñana marshlands and wetlands (1950s-1970s), as a reaction to the outward-inward agricultural process at the right bank.

At this point, it is worth mentioning that the focus of the present research is on the developments of rice and irrigation agriculture, and the protection-for-conservation race of the remaining Doñana marshlands, at the right bank. Rice agriculture developed over both banks of the estuary, in particular, over three of the main islands that the river formed in the estuary (northern part of Isla Mayor and Isla Mínima, right bank; Isla Menor, left bank) and the northern part of the area known as Low Guadalquivir (left bank). However, the whole left bank has followed a divergent historical trajectory producing a distinct outcome, which requires a different normative treatment that is not dealt with in this research.

\section{Link 2}

From the second half of the 19th century until 1937, the constitutional-level institutional matrix steadily provided massive increasing returns through top-down processes. In particular, it provided the lands surrounding the marshlands with exchange value and potential for diversification, as well as collective-action actors with easy access to - or even direct transference of - property rights, and financial incentives to develop infrastructure (Table A2.1, Appendix 2). Until the 1980s, such matrix continued to incentivize, at a larger scale, the mobilization of actors downstream, through the promotion of on-the-ground investments for the full transformation and agricultural exploitation of the marshlands (Table A2.1, Appendix 2). 


\section{Link 3}

During the self-reinforcement phase, certain political and power factors at the constitutional level played a key role in decreasing the attractiveness of alternative courses of action. According to Méndez et al. (2012) these factors include the increasing interventionism and bureaucratization of the authoritarian and autarchic government, and the action of the powerful technocratic corps of the State (mainly the forest and civil engineer corps). Regarding the latter, they refer, for example, to: coercive changes in property arrangements; the exclusion of "unproductive" marshland from nature conservation legislation; the promotion of economic maximization schemes for forestry in the vicinity of the marshlands (e.g., legislation such as the Forest Heritage Acts of 1941 and 1957) and agriculture in their interior (e.g., strategies such as the Guadalquivir-FAO Project, Almonte-Marismas Plan); cooption mechanisms within the emergent wetland conservation institutional regime; and the replacement of change champions by old-school engineers (e.g., J.A. Valverde). Despite the existence of several 'windows of opportunity' and the occurrence of several water and environmental crises, these constitutional-level mechanisms, operating mainly at the end of the self-reinforcement phase, imposed a command-and-control, 'inherent institutional logic' that curtailed institutional reorganization and renewal. In other words, they led to institutional reproduction and continuity (i.e. output inertia), and, eventually, to the rigid outcome.

\section{LITERATURE CITED}

Méndez, P. F., N. Isendahl, J. M. Amezaga, and L. Santamaría. 2012. Facilitating transitional processes in rigid institutional regimes for water management and wetland conservation: experience from the Guadalquivir Estuary. Ecology and Society 17(1): 26. http://dx.doi.org/10.5751/ES-04494$\underline{170126}$ 